Supplement of Atmos. Chem. Phys., 15, 12267-12281, 2015

http://www.atmos-chem-phys.net/15/12267/2015/

doi:10.5194/acp-15-12267-2015-supplement

(C) Author(s) 2015. CC Attribution 3.0 License.

(c) (i)

Supplement of

\title{
A qualitative comparison of secondary organic aerosol yields and composition from ozonolysis of monoterpenes at varying concentrations of $\mathrm{NO}_{2}$
}

D. C. Draper et al.

Correspondence to: J. L. Fry (fry@ reed.edu)

The copyright of individual parts of the supplement might differ from the CC-BY 3.0 licence. 


\section{Supplemental Information}

\section{Kinetics Modeling}

To account for uncertainties in measured $\mathrm{NO}_{2}$ concentrations and to constrain BVOC concentrations during experiments, each experiment was modeled to estimate the full time series of each species as well as to simulate the $1^{\text {st }}$ generation oxidation chemistry.

A simple kinetics box model was written to iteratively solve the differential rate laws for each species expected to be present in the chamber and to mimic the steady state flow conditions (constant addition and dilution) of the chamber, assuming instantaneous mixing. We start each model run allowing either $\mathrm{O}_{3}$ or $\mathrm{O}_{3}+\mathrm{NO}_{2}$ to reach steady state in the chamber. The laboratory $\mathrm{O}_{3}$ source is highly stable and thus matched well by the same initial parameters (flask concentration, flow rate) for every experiment. During this oxidant stabilization period, $\mathrm{NO}_{2}$ is the only chemical sink for $\mathrm{O}_{3}$, so we are able to tune the $\mathrm{NO}_{2}$ source concentration until the modeled and observed $\mathrm{O}_{3}$ time series match. This period is shown in Figure S. 1 in the shaded region. Once oxidant stabilization is achieved, BVOC is added. BVOC addition causes $\mathrm{O}_{3}$ to decay faster, now from both direct reaction with $\mathrm{BVOC}$ and additional $\mathrm{NO}_{3}$ formation from $\mathrm{O}_{3}+\mathrm{NO}_{2}$. Since $\left[\mathrm{NO}_{2}\right]$ is well characterized by the time BVOC is added, the BVOC source concentration is the only parameter that needs to be adjusted to match this final $\mathrm{O}_{3}$ decay (unshaded region in Figure S.1).

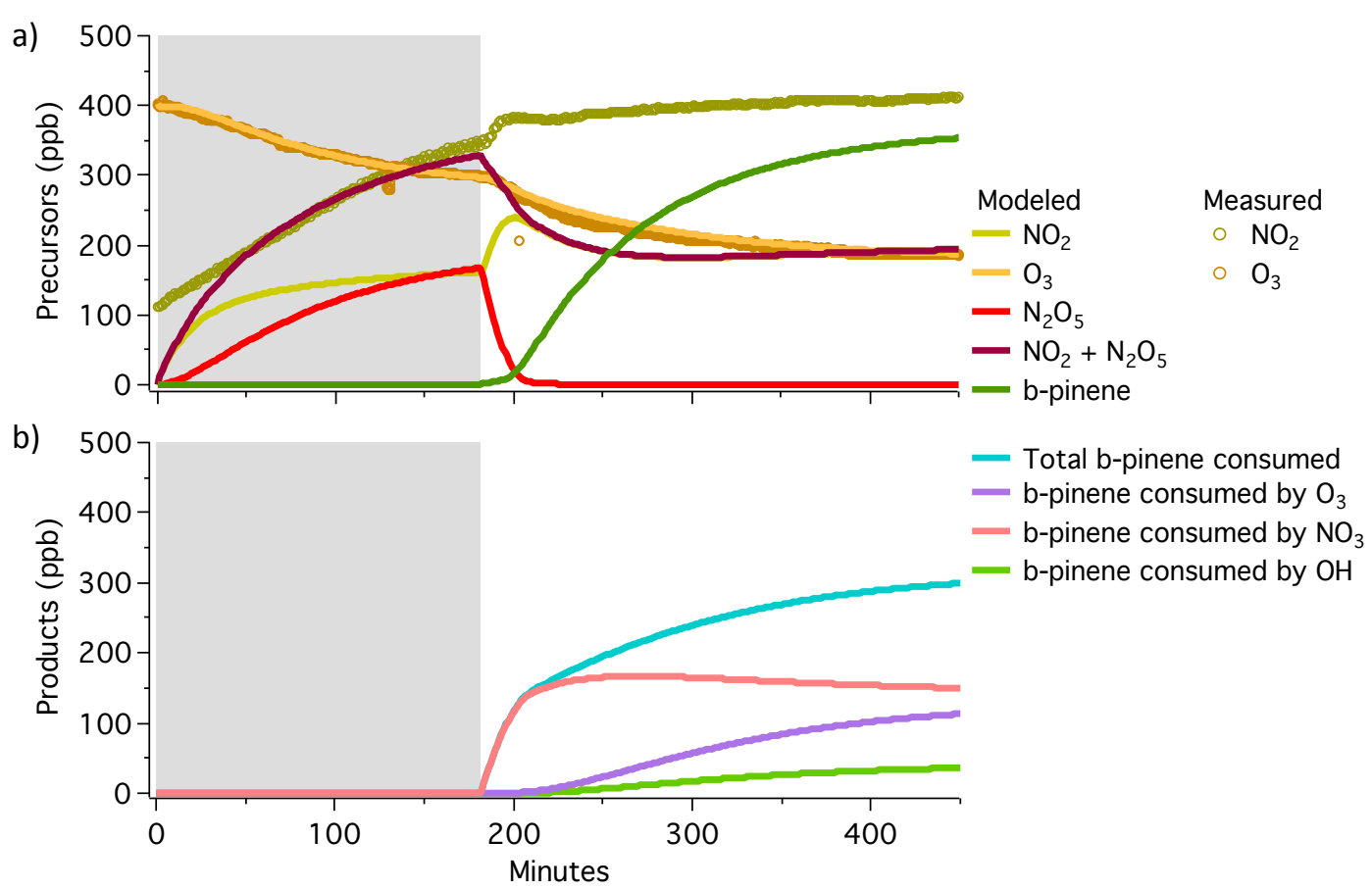

Figure S.1. Sample model run of $\beta$-pinene with the lowest $\mathrm{NO}_{2}$ concentration showing agreement between modeled and measured $\mathrm{O}_{3}$ and modeled $\mathrm{NO}_{2}+\mathrm{N}_{2} \mathrm{O}_{5}$ to measured $\mathrm{NO}_{2}$ (a, shaded region); agreement between measured and modeled $\mathrm{O}_{3}$ following the 
addition of $\beta$-pinene (a, unshaded region), and the instantaneous concentrations of bulk oxidation products from each oxidant (b).

The full list of rate constants used is described in Table S.1. Explicit kinetics data exists for all of the initial stages of chemistry (inter-oxidant reactions and BVOC oxidation). While these rate constants, for e.g. BVOC $+\mathrm{NO}_{3}$, are based on a small number of measurements and thus have uncertainty of order $20 \%$ associated with them, the least certain rate constants used here are those describing the fate of the $\mathrm{RO}_{2}$ radical formed following BVOC oxidation, which vary by orders of magnitude.

Table S.1. Rate constants used in kinetics model.

\begin{tabular}{|c|c|c|}
\hline Reaction & $\begin{array}{l}\mathrm{k}(298 \mathrm{~K})\left(\mathrm{cm}^{3} \mathrm{molec}^{-1} \mathrm{~s}^{-1}\right. \\
\text { unless otherwise indicated })\end{array}$ & Ref. \\
\hline $\mathrm{NO}_{2}+\mathrm{O}_{3}+\mathrm{M} \rightarrow \mathrm{NO}_{3}+\mathrm{O}_{2}+\mathrm{M}$ & $3.5 \times 10^{-17}$ & $\begin{array}{l}\text { Atkinson et al. } \\
(2004)\end{array}$ \\
\hline $\mathrm{NO}_{2}+\mathrm{NO}_{3} \rightarrow \mathrm{N}_{2} \mathrm{O}_{5}$ & $1.18 \times 10^{-12}$ & $\begin{array}{l}\text { Sander et al. } \\
(2011)\end{array}$ \\
\hline $\mathrm{N}_{2} \mathrm{O}_{5} \rightarrow \mathrm{NO}_{2}+\mathrm{NO}_{3}$ & $0.041 \mathrm{~s}^{-1}$ & $\begin{array}{l}\text { Sander et al. } \\
(2011)\end{array}$ \\
\hline $\mathrm{OH}+\mathrm{NO}_{2}+\mathrm{M} \rightarrow \mathrm{HNO}_{3}+\mathrm{M}$ & $1.1 \times 10^{-11}$ & $\begin{array}{l}\text { DeMore et al. } \\
\text { (1994) }\end{array}$ \\
\hline $\mathrm{OH}+\mathrm{HNO}_{3} \rightarrow \mathrm{NO}_{3}+\mathrm{H}_{2} \mathrm{O}$ & $2.7 \times 10^{-39}$ & $\begin{array}{l}\text { DeMore et al. } \\
\text { (1994) }\end{array}$ \\
\hline $\mathrm{NO}+\mathrm{NO}_{3} \rightarrow 2 \mathrm{NO}_{2}$ & $2.6 \times 10^{-11}$ & $\begin{array}{l}\text { DeMore et al. } \\
(1994)\end{array}$ \\
\hline $\mathrm{NO}+\mathrm{O}_{3} \rightarrow \mathrm{NO}_{2}+\mathrm{O}_{2}$ & $1.8 \times 10^{-14}$ & $\begin{array}{l}\text { DeMore et al. } \\
\text { (1994) }\end{array}$ \\
\hline $\begin{array}{c}\mathrm{NO}_{3}+\mathrm{BVOC} \rightarrow \text { products } \\
\left(\text { assumed } \mathrm{RO}_{2}\right) \\
\mathrm{BVOC}=\alpha \text {-pinene } \\
\beta \text {-pinene } \\
\Delta \text {-carene } \\
\text { limonene } \\
\end{array}$ & $\begin{array}{c}6.2 \times 10^{-12} \\
2.51 \times 10^{-12} \\
9.1 \times 10^{-12} \\
1.22 \times 10^{-11}\end{array}$ & $\begin{array}{l}\text { Atkinson and } \\
\text { Arey (2003) }\end{array}$ \\
\hline $\begin{array}{l}\mathrm{O}_{3}+\mathrm{BVOC} \rightarrow \text { products (assumed } \\
\left.\mathrm{RO}_{2}\right) \\
\mathrm{BVOC}=\alpha \text {-pinene } \\
\\
\quad \beta \text {-pinene } \\
\Delta \text {-carene } \\
\quad \text { limonene }\end{array}$ & $\begin{array}{l}8.4 \times 10^{-17} \\
1.5 \times 10^{-17} \\
3.7 \times 10^{-17} \\
2.1 \times 10^{-16}\end{array}$ & $\begin{array}{l}\text { Atkinson and } \\
\text { Arey (2003) }\end{array}$ \\
\hline $\begin{array}{c}\mathrm{OH}+\mathrm{BVOC} \rightarrow \text { products } \\
\left(\text { assumed } \mathrm{RO}_{2}\right) \\
\mathrm{BVOC}=\alpha \text {-pinene } \\
\quad \beta \text {-pinene } \\
\Delta \text {-carene } \\
\text { limonene }\end{array}$ & $\begin{array}{c}5.23 \times 10^{-11} \\
7.43 \times 10^{-11} \\
8.8 \times 10^{-11} \\
1.64 \times 10^{-10}\end{array}$ & $\begin{array}{l}\text { Atkinson and } \\
\text { Arey (2003) }\end{array}$ \\
\hline
\end{tabular}




\begin{tabular}{|c|c|c|}
\hline $\begin{array}{r}\mathrm{O}_{3}+\mathrm{BVOC} \rightarrow \mathrm{OH} \\
\mathrm{BVOC}=\alpha \text {-pinene } \\
\beta \text {-pinene } \\
\Delta \text {-carene } \\
\text { limonene }\end{array}$ & $\begin{array}{l}0.85 \times\left(8.4 \times 10^{-17}\right) \\
0.35 \times\left(1.5 \times 10^{-17}\right) \\
1.06 \times\left(3.7 \times 10^{-17}\right) \\
0.86 \times\left(2.1 \times 10^{-16}\right)\end{array}$ & $\begin{array}{l}\text { Atkinson and } \\
\text { Arey }(2003)\left(\mathrm{O}_{3}\right. \\
\text { rate constants); } \\
\text { Atkinson et al. } \\
\text { (1992) (OH } \\
\text { yields) }\end{array}$ \\
\hline $\mathrm{RO}_{2}+\mathrm{RO}_{2} \rightarrow$ products & $1 \times 10^{-15}-1 \times 10^{-12}$ & $\begin{array}{l}\text { Ziemann and } \\
\text { Atkinson (2012); } \\
\text { Ehn et al. (2014); } \\
\text { Orlando and } \\
\text { Tyndall (2012); } \\
\text { Lightfoot et al. } \\
\text { (1992) }\end{array}$ \\
\hline $\mathrm{RO}_{2}+\mathrm{NO}_{3} \rightarrow$ products & $2 \times 10^{-12}$ & $\begin{array}{l}\text { Vaughan et al. } \\
\text { (2006); Orlando } \\
\text { and Tyndall } \\
(2012)\end{array}$ \\
\hline $\mathrm{RO}_{2}+\mathrm{NO}_{2} \rightarrow \mathrm{ROONO}_{2}$ & $4.8 \times 10^{-11}$ & $\begin{array}{l}\text { Sander et al. } \\
\text { (2011) }\end{array}$ \\
\hline $\mathrm{ROONO}_{2} \rightarrow \mathrm{RO}_{2}+\mathrm{NO}_{2}$ & $22 \mathrm{~s}^{-1}$ & $\begin{array}{l}\text { Sander et al. } \\
\text { (2011) }\end{array}$ \\
\hline
\end{tabular}

The three most likely reaction partners to $\mathrm{RO}_{2}$ radicals in these experiments are $\mathrm{RO}_{2}$, $\mathrm{NO}_{3}$, and $\mathrm{NO}_{2} . \mathrm{HO}_{2}$ chemistry is not incorporated into the model, as we expect mainly tertiary $\mathrm{RO}_{2}$ to form and thus negligible $\mathrm{HO}_{2}$ production (Atkinson, 1997). We note that this lack of $\mathrm{HO}_{2}$ is a significant deviation from the real atmosphere where nighttime $\mathrm{HO}_{2}$ concentrations can be comparable to $\mathrm{RO}_{2}$ concentrations (Wolfe et al., 2014; AndresHernandez et al., 2013). In these experiments, we understand the relative rate constants of $\mathrm{RO}_{2}+\mathrm{RO}_{2}$ and $\mathrm{RO}_{2}+\mathrm{NO}_{3}$ to be the most substantial driver of how much BVOC reacts in the $\mathrm{NO}_{2}$-influenced experiments because they determine how much $\mathrm{NO}_{3}$ remains available to react with BVOC. $\mathrm{RO}_{2}+\mathrm{NO}_{2}$ will affect both the $\mathrm{RO}_{2}$ reservoir as well as $\mathrm{NO}_{3}$ formation potential, but since the products $\left(\mathrm{ROONO}_{2}\right)$ are understood to be fairly unstable (Sander et al., 2011), they decompose quickly back into $\mathrm{RO}_{2}$ and $\mathrm{NO}_{2}$ and thus are not as directly influential on [BVOC]. The $\mathrm{RO}_{2}+\mathrm{NO}_{3}$ rate constant has been measured to be $(1.8 \pm 1.5) \times 10^{-12} \mathrm{~cm}^{3} \mathrm{molec}^{-1} \mathrm{~s}^{-1}$ for multiple $\mathrm{RO}_{2}$ ranging from $\mathrm{C}_{2}$ to $\mathrm{C}_{6}$, so we approximate to $2 \times 10^{-12} \mathrm{~cm}^{3} \mathrm{molec}^{-1} \mathrm{~s}^{-1}$ in this study. It has not been measured for the $\mathrm{RO}_{2}$ radicals expected to be in this system, but the rate constant does not seem to show a strong dependence on size or branching of the $\mathrm{RO}_{2}$ and thus the molecules for which it has been measured are likely a good proxy for the chemistry here (Vaughan et al., 2006). The $\mathrm{RO}_{2}+\mathrm{RO}_{2}$ rate constants that have been measured, however, are much more variable. Examination of trends in the literature shows that increasing the size (\# $\mathrm{C}$ atoms) of the $\mathrm{RO}_{2}$ radical can increase its self-reaction rate constant by multiple orders of magnitude; increasing branching of the $\mathrm{RO}_{2}$ (from primary to tertiary) decreases the rate constant by multiple orders of magnitude; functional group substitution at the $\beta$-carbon can increase the rate constant by up to two orders of 
magnitude (Ziemann and Atkinson, 2012; Orlando and Tyndall, 2012; Lightfoot et al., 1992).

In each monoterpene system, we expect to be making mainly tertiary, $\mathrm{NO}_{3}$ functionalized $\mathrm{C}_{10} \mathrm{RO}_{2}$. Having a $\beta$-nitrato tertiary $\mathrm{RO}_{2}$ gives us our low estimate of the $\mathrm{RO}_{2}+\mathrm{RO}_{2}$ rate constant $\left(\mathrm{k}=1 \times 10^{-15} \mathrm{~cm}^{3}\right.$ molec $\left.^{-1} \mathrm{~s}^{-1}\right)$ (Ziemann and Atkinson, 2012; Atkinson, 1997). These $\mathrm{C}_{10}$ peroxy radicals are at least 4 carbons bigger than any with measured rate constants, though, and thus it is entirely possible that the real rate constant is a few orders of magnitude higher. For this study we choose

$\mathrm{k}=1 \times 10^{-12} \mathrm{~cm}^{3}$ molec $^{-1} \mathrm{~s}^{-1}$ as a reasonable upper limit, since it has been supported by measurements of product formation (Ehn et al., 2014). This difference of 3 orders of magnitude dominates the uncertainty for this modeling approach. Using each of these two bounding $\mathrm{RO}_{2}+\mathrm{RO}_{2}$ rate constants, we can then determine the BVOC source concentration that matches the observed $\mathrm{O}_{3}$ decay, thus giving us a best estimate range of [BVOC].

Once the precursor concentrations are decided upon, the percentage of BVOC reacted by each oxidant is calculated within the model (Figure S.2). Since no OH scavenger was used during experiments, we assume that stabilized Criegee intermediates from ozonolysis produced $\mathrm{OH}$ at the yields reported by (Atkinson et al., 1992; shown in Table S.1).

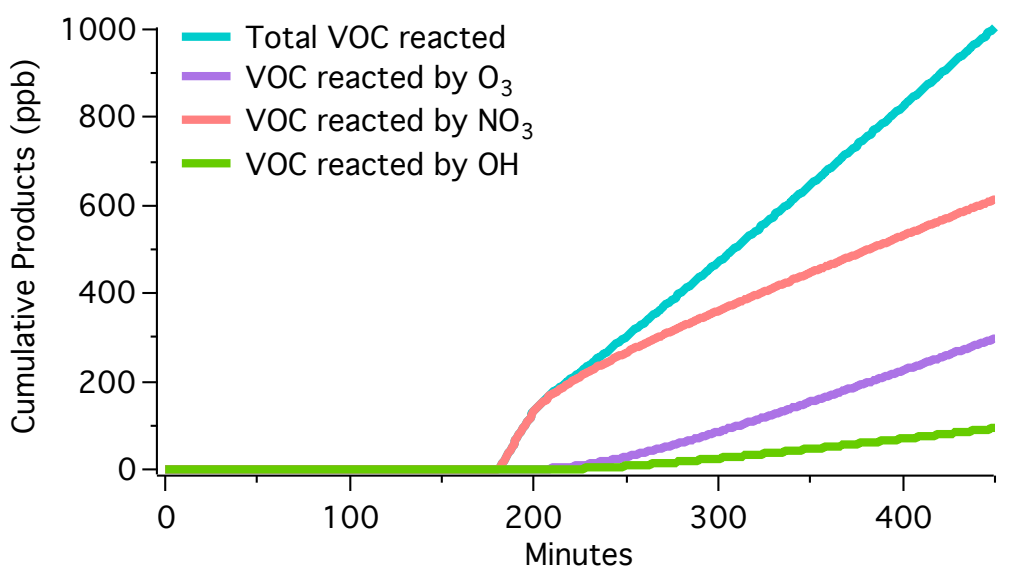

Figure S.2. Sample model run of $\beta$-pinene with the lowest $\mathrm{NO}_{2}$ concentration showing the cumulative oxidation products from each oxidant.

\section{BVOC measurement and characterization of uncertainties}

As described in the main body of the text, the BVOC delivery system was designed to maintain a constant vapor pressure of the BVOC in the source flask, which could then be flowed continuously into the chamber. This constant vapor pressure was achieved by injecting a small $(<0.2 \mathrm{~mL})$ liquid sample of the monoterpene into a flask submerged into a chiller bath held at the appropriate temperature to give a concentration of $100 \mathrm{ppm}$ in the headspace of the flask (Figure S.3). This methodology relies on several assumptions. We assume that the vapor pressure-driven concentration (and temperature) inside the flask reaches equilibrium within the residence time of gas in the flask. (14 $\mathrm{mL} / \mathrm{min}$ air flow through a $100 \mathrm{~mL}$ flask $\approx 7 \mathrm{~min}$ ). We also assume that the surface area of the liquid sample remains constant over time. 


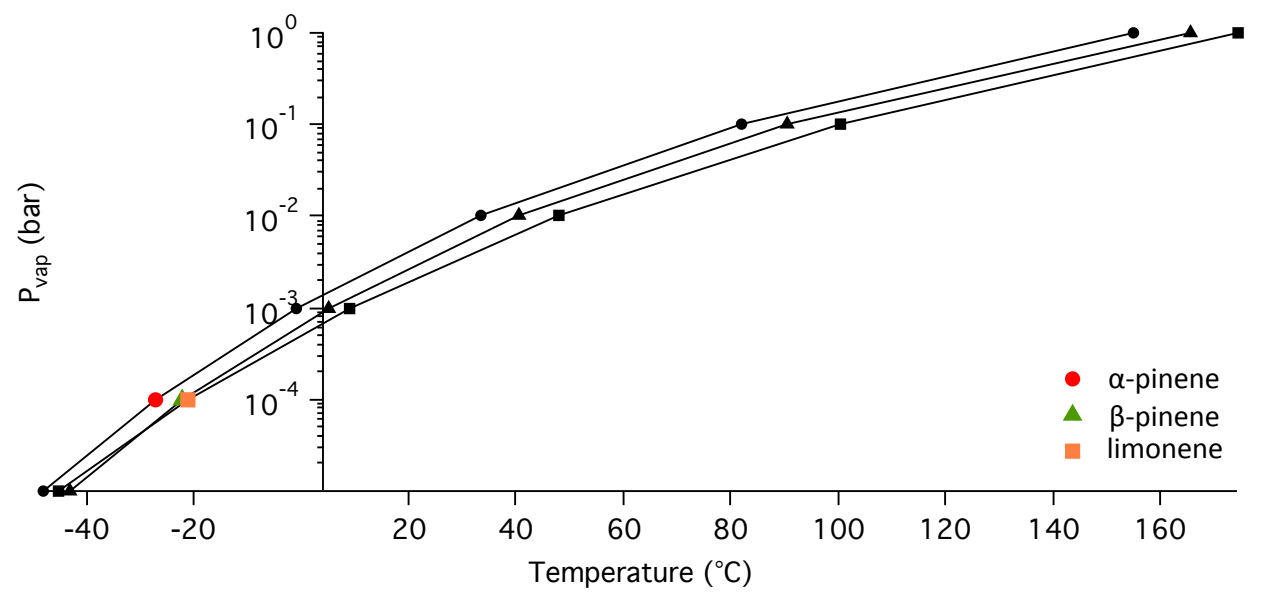

Figure S.3. Temperature dependence of vapor pressure of $\alpha$-pinene, $\beta$-pinene, and limonene (Haynes et al., 2012). $\Delta$-3-carene is assumed to reach the target vapor pressure at $-25^{\circ} \mathrm{C}$, between $\alpha$-pinene and $\beta$-pinene.

To obtain an independent estimate of what the actual gas-phase chamber concentrations were during each experiment, data was fit using the gas-phase kinetics model described above, where $\mathrm{NO}_{2}$ and $\mathrm{BVOC}$ are both tunable to fit the observed $\mathrm{O}_{3}$ decay. The largest source of uncertainty in the model affecting the predicted BVOC concentration is the $\mathrm{RO}_{2}+\mathrm{RO}_{2}$ rate constant. We chose a range shown in Table S.1, spanning three orders of magnitude in $\mathrm{k}_{\mathrm{RO} 2+\mathrm{RO} 2}$, which predicts a range of $\mathrm{BVOC}$ concentrations that varies by no more than about $25 \%$. This source of uncertainty drives our precision estimate for the amount of BVOC consumed and is incorporated into yield calculations in Section 3.2 and shown in Figure 4. Here the BVOC time series generated by using each of the low and high $\mathrm{k}_{\mathrm{RO} 2+\mathrm{RO} 2}$ values were averaged together for each individual experiment, and the standard deviation was taken to be the error on the $\Delta \mathrm{HC}$ values.

Additionally, the model calculates the BVOC concentration assuming a single BVOC + oxidant reaction, and therefore limonene's $\triangle H C$ may be an overestimate since limonene has two double bonds that can potentially react with $\mathrm{O}_{3}$ or $\mathrm{NO}_{3}$ (Zhang et al., 2006).

\section{Wall loss characterization}

Aerosol wall losses in this chamber were characterized according to the method employed by previous studies (McMurry et al., 1985; Fry et al., 2014). An approximately $0.02 \mathrm{M}$ solution of $\left(\mathrm{NH}_{4}\right)_{2} \mathrm{SO}_{4}$ was atomized, dried through a diffusion dryer, and measured directly into the SEMS to obtain a known input aerosol distribution. The concentration of the seed solution was optimized to span the full size range (20-800 $\mathrm{nm}$ ) of aerosol that was observed during experiments. The seed aerosol at the same flow rate was then introduced into the chamber and measured with the SEMS at the outlet of the chamber (Figure S.5a). First order size-dependent wall loss coefficients, $\beta\left(D_{p}\right)$, were 
calculated according to Eq. 1, using average size distributions going into $\left(\mathrm{N}_{\text {in }}\right)$ and coming out of the chamber $\left(\mathrm{N}_{\text {out }}\right)$, the chamber flow rate $(\mathrm{Q})$, chamber volume $(\mathrm{V})$, and assuming the chamber to behave as a continuously stirred tank reactor.

$$
\beta\left(D_{p}\right)=\left(\frac{Q}{V}\right)\left[\left(\frac{N_{\text {in }}\left(D_{p}\right)}{N_{\text {out }}\left(D_{p}\right)}\right)-1\right]
$$

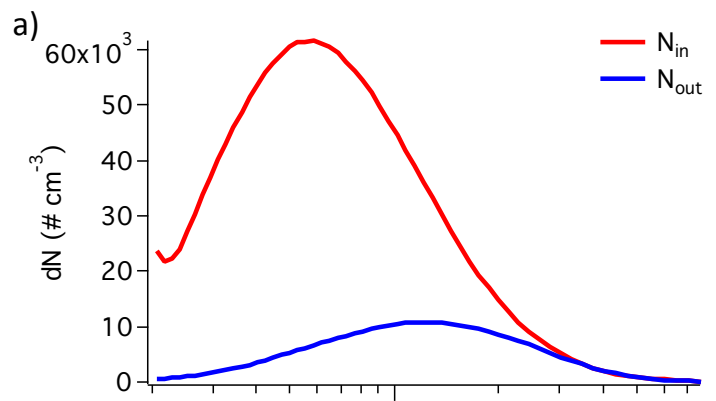

c)

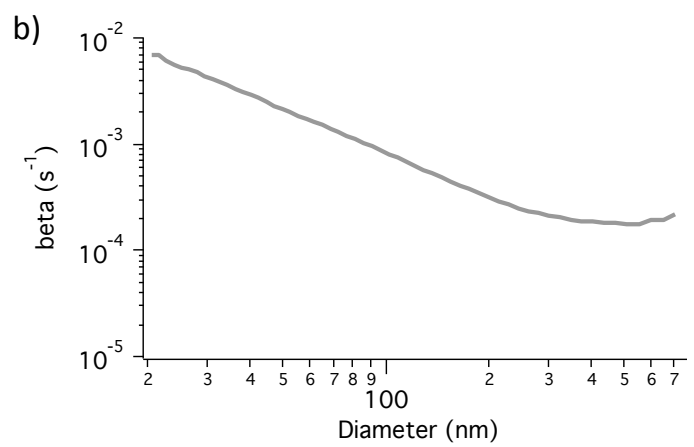

d)
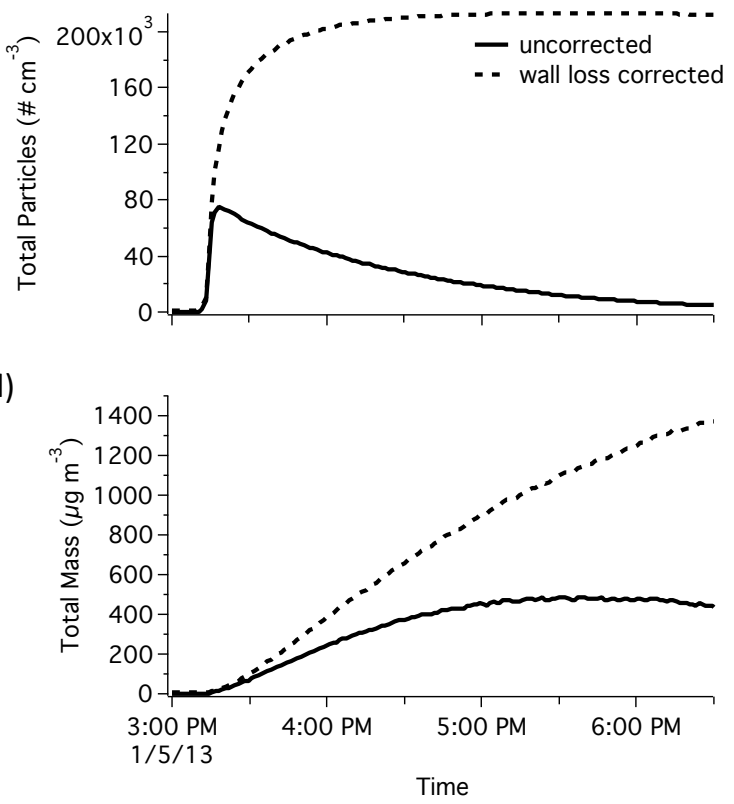

Figure S.5. (a) Input and output number size distributions of the seed aerosol entering and leaving the chamber; (b) Size-dependent wall loss rates; Uncorrected and corrected time series of total aerosol number concentrations (c) and mass (d) from a representative experiment $\left(\alpha\right.$-pinene $\left.+\mathrm{O}_{3}\right)$.

Raw size distributions from experiments were corrected cumulatively for wall losses (McMurry et al., 1985; Fry et al., 2014). At each time step, loss rates were multiplied by the raw size distribution to determine how many particles in each size bin were lost to the walls. These losses were then added back to the corrected dataset. This process assumes that any particle lost to the walls remains there and does not grow past the size it was when it was lost. This method provides reasonable corrections for total mass and total number of particles produced, but adding back static sized particles obscures observed growth dynamics. Figure S.6 shows a representative uncorrected and corrected growth event, illustrating how the particles added back remain at the size they were when they were lost to the walls. 


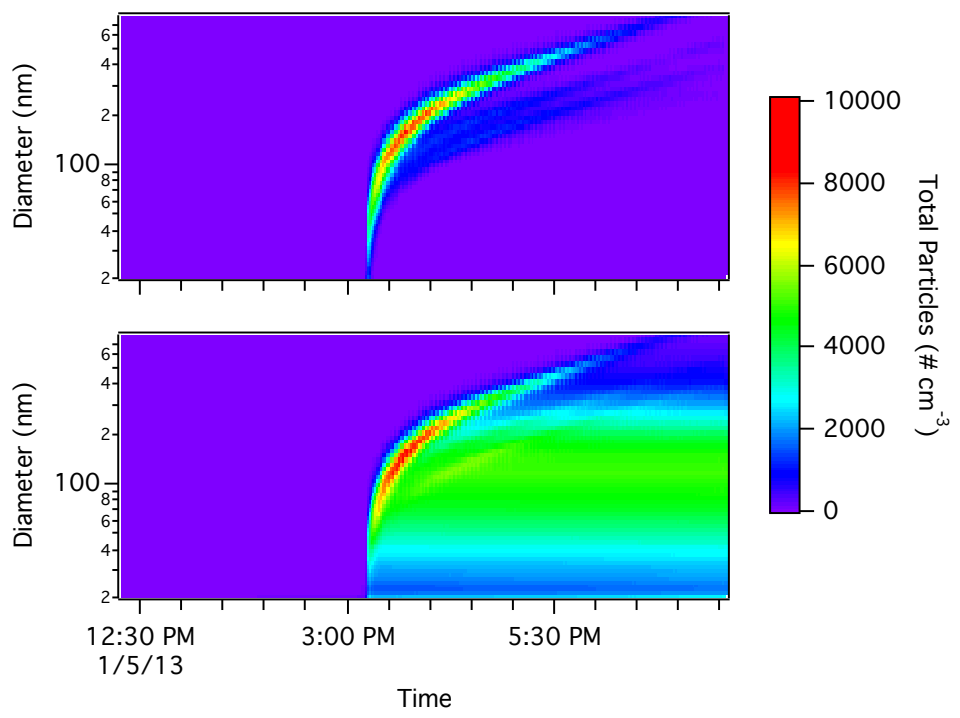

Figure S.6. Uncorrected (top) and wall loss corrected (bottom) aerosol growth events from a representative experiment $\left(\alpha\right.$-pinene $\left.+\mathrm{O}_{3}\right)$.

\section{Characterization of SEMS precision}

To assess the precision of the SEMS measurement and reproducibility of our experimental protocal, we conducted two replicate $\alpha$-pinene $+\mathrm{O}_{3}$ experiments. Since they are $\mathrm{O}_{3}$-only experiments, we do not have a way to constrain the uncertainty on $\Delta \mathrm{HC}$, so we assume that all uncertainty on the aerosol mass yield is due to the precision of the $\Delta \mathrm{M}$ measurement. To calculate the relative error on this measurement, we interpolated the total mass time series from each of these two experiments onto a common $\Delta \mathrm{HC}$ trace. From these two interpolated $\Delta \mathrm{M}$ traces, we could calculate the average $\Delta \mathrm{M}$ and standard deviation, which provided the relative error trace shown in Figure S.7. The relative error was not constant with $\triangle \mathrm{HC}$, so we conservatively chose the highest stable value $(15 \%)$ to use as the error on $\Delta \mathrm{M}$ for all experiments. 


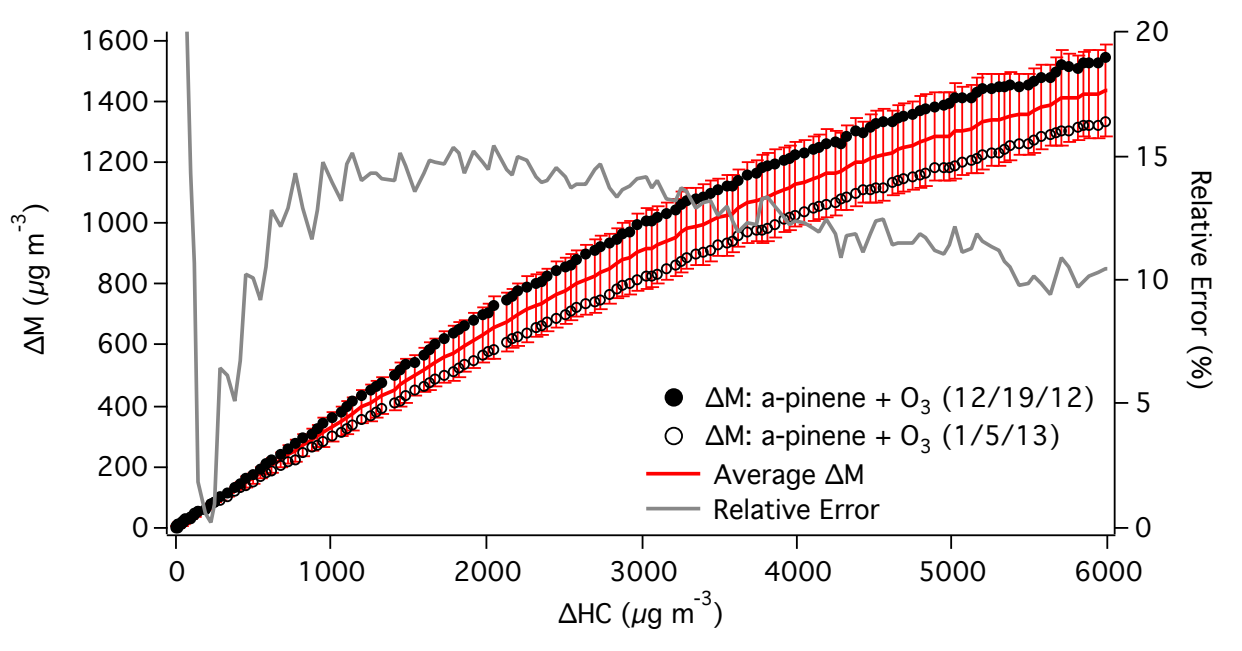

Figure S.7. The average and standard deviation of $\Delta \mathrm{M}$ at a given amount of reacted hydrocarbon were calculated (red trace) from two replicate measurements of $\alpha$-pinene + $\mathrm{O}_{3}$ made in the REC (black circles). The standard deviation was used to calculate the relative error associated with $\Delta \mathrm{M}$ measurements (grey trace). Relative error on $\Delta \mathrm{M}$ was not constant over the course of each full experiment, so we conservatively take the highest stable value $-15 \%$ - as the relative error on $\Delta \mathrm{M}$ for all experiments.

\section{Individual Oxidant Contributions: $\Delta$-carene and limonene}

Figure S.8 is an extension of Figure 5 in the main text showing qualitatively similar behavior from both $\Delta$-carene and limonene to $\beta$-pinene insofar as all three monoterpenes produce some aerosol mass during the period of the experiment kinetically dominated by $\mathrm{NO}_{3}$ oxidation. Additionally, the minimum in peroxynitrate formation correlates well with the initiation of aerosol formation in all but the $\Delta$-carene with medium $\mathrm{NO}_{2}$ experiment. 


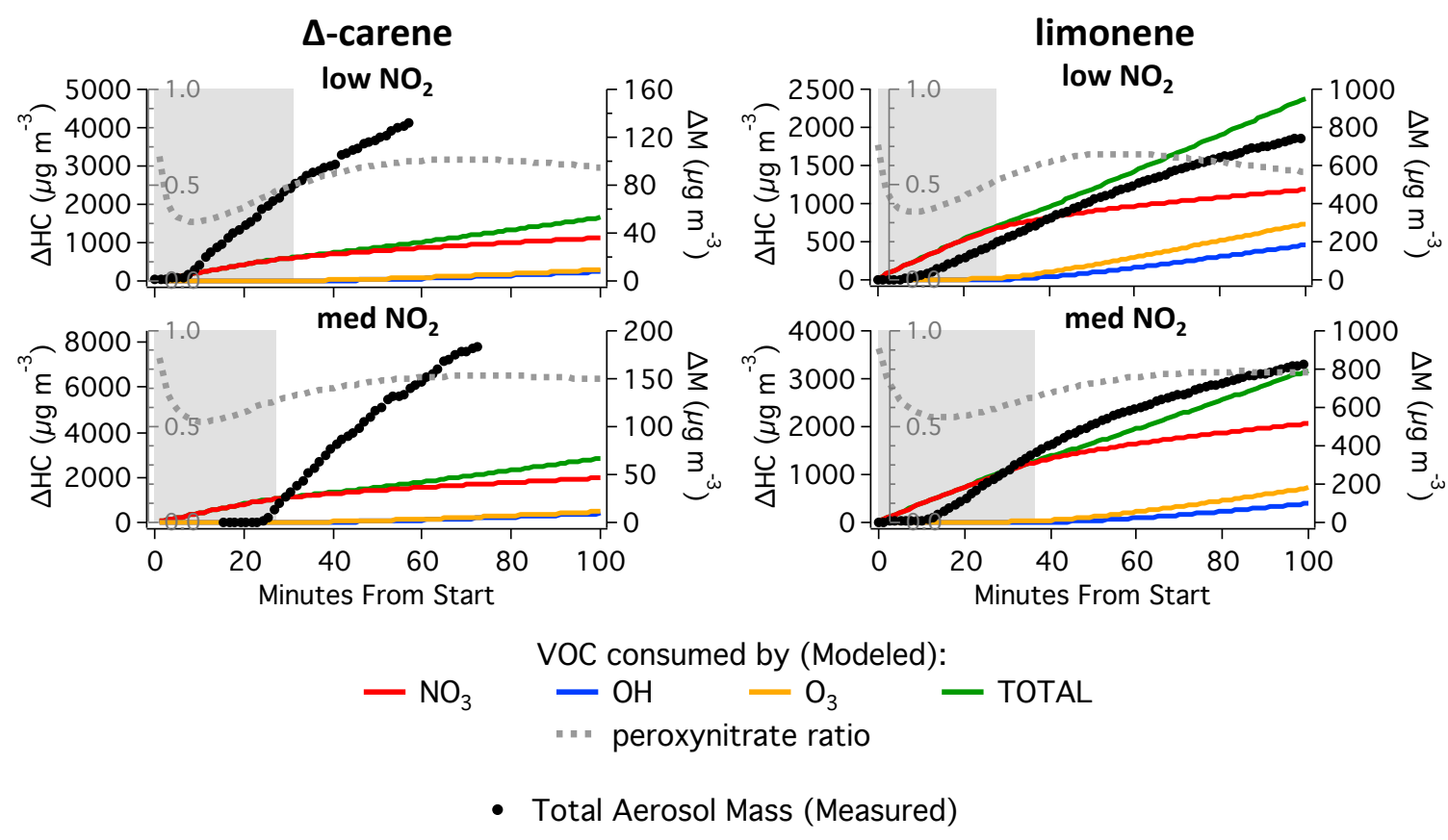

Figure S.8. Time series of wall loss corrected aerosol mass (right axis) and VOC consumed by each oxidant (left axis) for $\Delta^{3}$-carene and limonene at low and medium $\mathrm{NO}_{2}$ concentrations, highlighting how much aerosol is produced at times dominated by $\mathrm{NO}_{3}{ }^{-}$ oxidation (shaded regions). $\Delta \mathrm{HC}$ values shown are the lower limits calculated using the lowest $\mathrm{RO}_{2}+\mathrm{RO}_{2}$ rate constant $\left(10^{-15} \mathrm{~cm}^{3} \mathrm{molec}^{-1} \mathrm{~s}^{-1}\right)$, which gives the low limit on how much $\mathrm{NO}_{3}$ reacts with VOC directly. Dashed grey traces (inner left grey axis) represent the ratio of $\mathrm{RO}_{2}+\mathrm{NO}_{2}$ products that are present in the chamber (instantaneous concentration) relative to the sum of the instantaneous concentrations of $\mathrm{RO}_{2}+\mathrm{RO}_{2}$, $\mathrm{RO}_{2}+\mathrm{NO}_{3}$, and $\mathrm{RO}_{2}+\mathrm{NO}_{2}$ products. This ratio is a representation of the time dependence of peroxynitrate formation in the chamber.

\section{Identification of products from HPLC-ESI-MS}

Chromatographic separation coupled to high resolution mass spectrometry allows for relatively straightforward identification of products. A list of compounds was generated for each experiment from both positive and negative ion modes, using Agilent MassHunter software and employing a minimum relative intensity threshold of $1.5 \%$ of the highest intensity peak. Compound lists were then manually adjusted to ensure accurate ion adduct assignments, removal of redundant adducts at identical retention times, and formula assignments with consistent relative mass error. Although the product threshold was governed by relative intensity instead of an absolute cutoff, each of the software-identified products was manually searched for, at the same retention time, in the other experiments studying the same monoterpene. If any of those products were not identified by the software, but present at $>3000$ counts, they were added back to the product list for that experiment. This was done to minimize reporting $\mathrm{NO}_{3}$ products that "are not formed" by $\mathrm{O}_{3}$ oxidation, and vice versa, if they are formed but were missed by the software. Table S.2 shows the complete list of products included in Table 6 and 
Figure 7. Table S.3 lists the most intense peaks and includes proposed structures according to specific products other studies have identified in similar systems as well as speculative structures simply showing that some of the high molecular weight products observed could be reasonably formed via oligomerization reactions of known monomers from these systems. 
Table S.2. SOA compound formulae identified by HPLC-ESI-MS. Tables organized into $\mathrm{O}_{3}$ and $\mathrm{NO}_{3}$ regimes for each monoterpene, where any compound present in both oxidant regimes is only listed in the $\mathrm{O}_{3}$ regime. Unless otherwise stated (see notes), compounds were observed only in the positive ion mode. Masses and formulae refer to the precursor (non-adduct) compound, which is reported as the nominal mass for any adducts misassigned by the software.

\begin{tabular}{|c|c|c|c|c|}
\hline \multicolumn{5}{|c|}{$\alpha$-pinene $+\mathrm{O}_{3}$} \\
\hline Mass & Formula & $\begin{array}{l}\text { Relative Mass } \\
\text { Difference (MFG) }\end{array}$ & RT & Notes \\
\hline 184.1115 & C10 H16 O3 & -8.32 & 7.1 & $\mathrm{~b}$ \\
\hline 106.079 & C8 H10 & -6.91 & 7.184 & \\
\hline 168.117 & C10 H16 O2 & -11.65 & 7.212 & \\
\hline 182.1328 & $\mathrm{C} 11 \mathrm{H} 18 \mathrm{O} 2$ & -11.42 & 7.213 & \\
\hline 168 & $\mathrm{C} 10 \mathrm{H} 16 \mathrm{O} 2$ & -13.15 & 8.685 & \\
\hline 168 & C10 H16 O2 & -7.64 & 9.109 & \\
\hline 152.1214 & $\mathrm{C} 10 \mathrm{H} 16 \mathrm{O}$ & -8.47 & 9.377 & \\
\hline 376.193 & $\mathrm{C} 21 \mathrm{H} 28 \mathrm{O} 6$ & -11.76 & 10.238 & \\
\hline 243.1852 & $\mathrm{C} 13 \mathrm{H} 25 \mathrm{~N} \mathrm{O} 3$ & -7.36 & 11.029 & $\mathrm{~b}$ \\
\hline 421 & $\mathrm{C} 21 \mathrm{H} 27 \mathrm{~N} \mathrm{O} 8$ & -10.33 & 11.67 & $\mathrm{~b}$ \\
\hline 289.2647 & $\mathrm{C} 16 \mathrm{H} 35 \mathrm{~N} \mathrm{O} 3$ & -10.5 & 11.877 & \\
\hline 216.1756 & $\mathrm{C} 12 \mathrm{H} 24 \mathrm{O} 3$ & -14.1 & 11.971 & \\
\hline 128.121 & $\mathrm{C} 8 \mathrm{H} 16 \mathrm{O}$ & -6.74 & 11.971 & \\
\hline 287.2863 & C17 H37 N O2 & -13.31 & 11.982 & \\
\hline 229.2437 & $\mathrm{C} 14 \mathrm{H} 31 \mathrm{~N} \mathrm{O}$ & -13.81 & 12.022 & \\
\hline 216.1755 & $\mathrm{C} 12 \mathrm{H} 24 \mathrm{O} 3$ & -13.78 & 12.027 & \\
\hline 287.285 & $\mathrm{C} 17 \mathrm{H} 37 \mathrm{~N} \mathrm{O} 2$ & -9.01 & 12.242 & \\
\hline 240.0714 & C10 H12 N2 O5 & & 12.694 & $\mathrm{c}$ \\
\hline 276.1769 & $\mathrm{C} 17 \mathrm{H} 24 \mathrm{O} 3$ & -15.91 & 12.697 & \\
\hline 220.1128 & C13 H16 O3 & -13.08 & 12.697 & \\
\hline 466 & $\mathrm{C} 33 \mathrm{H} 22 \mathrm{O} 3$ & 5.57 & 12.716 & $\mathrm{c}$ \\
\hline 342.152 & $\mathrm{C} 20 \mathrm{H} 22 \mathrm{O} 5$ & -15.27 & 13.145 & $\mathrm{a}$ \\
\hline 148.0178 & $\mathrm{C} 8 \mathrm{H} 4 \mathrm{O} 3$ & -11.81 & 13.293 & $\mathrm{~d}$ \\
\hline 278.1553 & $\mathrm{C} 16 \mathrm{H} 22 \mathrm{O} 4$ & -12.67 & 13.294 & $\mathrm{~d}$ \\
\hline 204.0815 & $\mathrm{C} 12 \mathrm{H} 12 \mathrm{O} 3$ & -13.98 & 13.294 & $\mathrm{~d}$ \\
\hline 278.1554 & $\mathrm{C} 16 \mathrm{H} 22 \mathrm{O} 4$ & -12.79 & 13.454 & $d$ \\
\hline 148.0179 & $\mathrm{C} 8 \mathrm{H} 4 \mathrm{O} 3$ & -12.3 & 13.455 & d \\
\hline 228.2052 & C14 H28 O2 & 16.29 & 13.528 & $\mathrm{c}$ \\
\hline
\end{tabular}

a) Peak only appears in $\mathrm{O}_{3}$ experiment.

b) Peak present in both positive and negative ion mode.

c) Peak present in negative ion mode only.

d) Known phthalate impurity. 


\begin{tabular}{|l|l|l|l|l|}
\hline \multicolumn{5}{|c|}{ a-pinene + NO N $_{3}$ excluding products listed in $\alpha$-pinene $+\mathrm{O}_{3}$ ) } \\
\hline Mass & Formula & $\begin{array}{l}\text { Relative Mass } \\
\text { Difference (MFG) }\end{array}$ & RT & Notes \\
\hline 186.0863 & C9 H14 O4 & 15.8 & 5.802 & c \\
\hline 138.106 & C9 H14 O & -10.84 & 7.1 & \\
\hline 114.0692 & C6 H10 O2 & -9.8 & 7.1 & \\
\hline 213 & C10 H15 N O4 & -11.54 & 9.763 & \\
\hline 201 & C9 H15 N O4 & -14.11 & 9.951 & \\
\hline 152.1207 & C10 H16 O & -3.79 & 11.236 & \\
\hline 215 & C10 H17 N O4 & -10.25 & 11.236 & \\
\hline 231 & C10 H17 N O5 & -12.33 & 11.315 & \\
\hline 366 & C20 H30 O6 & -12.89 & 11.684 & \\
\hline 310 & C18 H30 O4 & -11.55 & 11.867 & \\
\hline 260 & C10 H16 N2 O6 & -10.05 & 12.135 & \\
\hline 383.1987 & C19 H29 N O7 & -11.09 & 13.433 & b \\
\hline 256.2363 & C16 H32 O2 & 15.18 & 17.179 & c, \\
\hline 215.0551 & C12 H9 N O3 & 14.75 & 11.425 & c \\
\hline 229.2426 & C14 H31 N O & -9.08 & 11.857 & \\
\hline 276.176 & C17 H24 O3 & -12.47 & 12.434 & \\
\hline
\end{tabular}

a) Peak only appears in $\mathrm{O}_{3}$ experiment.

b) Peak present in both positive and negative ion mode.

c) Peak present in negative ion mode only.

d) Known phthalate impurity.

\begin{tabular}{|l|l|l|l|l|}
\hline \multicolumn{5}{|c|}{ 及-pinene + O } \\
\hline Mass & Formula & $\begin{array}{l}\text { Relative Mass } \\
\text { Difference (MFG) }\end{array}$ & RT & Notes \\
\hline 186.091 & C9 H14 O4 & -9.51 & 5.902 & \\
\hline 154.1001 & C9 H14 O2 & -4.94 & 5.923 & \\
\hline 169.1112 & C9 H12 O2 & -5.26 & 6.125 & \\
\hline 94.0789 & C7 H10 & -7.3 & 6.952 & \\
\hline 108.0942 & C8 H12 & -2.54 & 6.953 & \\
\hline 154.0998 & C9 H14 O2 & -2.87 & 6.954 & \\
\hline 184.111 & C10 H16 O3 & -5.5 & 7.1 & b \\
\hline 182.1315 & C11 H18 O2 & -4.44 & 7.21 & \\
\hline 168.1159 & C10 H16 O2 & -5.42 & 7.211 & \\
\hline 154.0999 & C9 H14 O2 & -3.27 & 7.579 & \\
\hline 170 & C10 H18 O2 & -5.75 & 8.861 & \\
\hline 138.1048 & C9 H14 O & -2.59 & 9.058 & \\
\hline 82.0427 & C5 H6 O & -10.45 & 9.06 & \\
\hline 358 & C17 H26 O8 & -8.98 & 9.231 & a, b \\
\hline 138.1053 & C9 H14 O & -5.79 & 9.286 & \\
\hline 170 & C10 H18 O2 & -6.1 & 9.348 & \\
\hline 376.1919 & C21 H28 O6 & -8.85 & 10.24 & \\
\hline
\end{tabular}




\begin{tabular}{|l|l|l|l|l|}
\hline 370.2015 & C19 H30 O7 & -6.22 & 10.782 & a, b \\
\hline 243.1849 & C13 H25 N O3 & -6.05 & 11.03 & b \\
\hline 421 & C21 H27 N O8 & -8.43 & 11.673 & b \\
\hline 287.2845 & C17 H37 N O2 & -7.21 & 11.985 & \\
\hline 287.284 & C17 H37 N O2 & -5.3 & 12.245 & \\
\hline 240.0706 & & 14.02 & 12.695 & a, c \\
\hline 278.1537 & C16 H22 O4 & -6.77 & 13.293 & d \\
\hline 148.0165 & C8 H4 O3 & -3.24 & 13.293 & d \\
\hline 278.1536 & C16 H22 O4 & -6.56 & 13.452 & d \\
\hline 148.0164 & C8 H4 O3 & -2.41 & 13.452 & d \\
\hline 204.0803 & C12 H12 O3 & -8.04 & 13.453 & d \\
\hline 256.2354 & C16 H32 O2 & 18.66 & 17.254 & c \\
\hline
\end{tabular}
a) Peak only appears in $\mathrm{O}_{3}$ experiment.
b) Peak present in both positive and negative ion mode.
c) Peak present in negative ion mode only.
d) Known phthalate impurity.

\begin{tabular}{|c|c|c|c|c|}
\hline \multicolumn{5}{|c|}{$\boldsymbol{\beta}$-pinene $+\mathbf{N O}_{3}$ (excluding products listed in $\beta$-pinene $+\mathrm{O}_{3}$ ) } \\
\hline Mass & Formula & $\begin{array}{l}\text { Relative Mass } \\
\text { Difference (MFG) }\end{array}$ & RT & Notes \\
\hline 170 & $\mathrm{C} 10 \mathrm{H} 18 \mathrm{O} 2$ & -2.67 & 7.173 & \\
\hline 227.0811 & C10 H13 N O5 & -7.5 & 8.255 & \\
\hline 245.0857 & C10 H15 N O6 & 17.12 & 8.901 & $\mathrm{c}$ \\
\hline 229 & C10 H15 N O5 & -4.38 & 9.245 & \\
\hline 186 & $\mathrm{C} 10 \mathrm{H} 18 \mathrm{O} 3$ & -1.84 & 9.614 & \\
\hline 264.133 & $\mathrm{C} 10 \mathrm{H} 20 \mathrm{~N} 2 \mathrm{O} 6$ & -3.33 & 9.644 & \\
\hline 230.1281 & $\mathrm{C} 10 \mathrm{H} 18 \mathrm{~N} 2 \mathrm{O} 4$ & -6.15 & 9.767 & \\
\hline 277.1107 & C11 H19 N O7 & 19.83 & 9.789 & $\mathrm{c}$ \\
\hline 184.1059 & C10 H16 O3 & & 10.358 & $\mathrm{c}$ \\
\hline 227.1904 & C13 H25 N O2 & -8.17 & 11.107 & \\
\hline 229.0909 & C10 H15 N O5 & 17.94 & 11.226 & $\mathrm{c}$ \\
\hline 230.1278 & C10 H18 N2 O4 & -4.77 & 11.233 & \\
\hline 215 & C10 H17 N O4 & -2.94 & 11.241 & \\
\hline 197.1066 & C10 H15 N O3 & -7.08 & 11.382 & \\
\hline 215 & C10 H17 N O4 & -2.5 & 11.382 & \\
\hline 134.1094 & C10 H14 & 0.92 & 11.382 & \\
\hline 156.1117 & & & 11.386 & $\mathrm{c}$ \\
\hline 96.0581 & C6 H8 O & -5.97 & 11.386 & \\
\hline 152.1197 & $\mathrm{C} 10 \mathrm{H} 16 \mathrm{O}$ & 2.44 & 11.386 & \\
\hline 217.1685 & $\mathrm{C} 11 \mathrm{H} 23 \mathrm{~N} \mathrm{O} 3$ & -3.26 & 11.415 & \\
\hline 215.054 & C12 H9 N O3 & 19.61 & 11.434 & $\mathrm{c}$ \\
\hline 215 & C10 H17 N O4 & -3.42 & 11.537 & \\
\hline 277.1109 & C11 H19 N O7 & 18.8 & 11.734 & $\mathrm{c}$ \\
\hline 231 & C10 H17 N O5 & -2.01 & 11.742 & \\
\hline
\end{tabular}




\begin{tabular}{|l|l|l|l|l|}
\hline 260.1382 & C11 H20 N2 O5 & -3.77 & 11.944 & \\
\hline 260 & C10 H16 N2 O6 & -3.69 & 12.139 & \\
\hline 260 & C10 H16 N2 O6 & -3.16 & 12.722 & \\
\hline 397.2037 & C20 H31 N O7 & 15.95 & 13.802 & c \\
\hline 383.1882 & C19 H29 N O7 & 16.06 & 13.845 & $\mathrm{c}$ \\
\hline 430.2329 & C20 H34 N2 O8 & -3.11 & 14.298 & \\
\hline 413.1976 & C20 H31 N O8 & 17.88 & 14.316 & $\mathrm{c}$ \\
\hline 413 & C21 H35 N O7 & -3.6 & 14.858 & \\
\hline 385 & C19 H31 N O7 & -4.71 & 15.6 & \\
\hline 429 & C21 H35 N O8 & -3.15 & 15.608 & \\
\hline 431.209 & C20 H33 N O9 & 15.11 & 15.629 & $\mathrm{c}$ \\
\hline 415 & C20 H33 N O8 & -5.37 & 15.895 & \\
\hline 442 & C20 H30 N2 O9 & -4.83 & 15.977 & \\
\hline 428.2174 & C20 H32 N2 O8 & -3.65 & 16.684 & b \\
\hline 444 & C20 H32 N2 O9 & -5.54 & 16.807 & \\
\hline 460 & C20 H32 N2 O10 & -2.88 & 17.298 & \\
\hline
\end{tabular}
a) Peak only appears in $\mathrm{O}_{3}$ experiment.
b) Peak present in both positive and negative ion mode.
c) Peak present in negative ion mode only.
d) Known phthalate impurity.

\begin{tabular}{|l|l|l|l|l|}
\hline \multicolumn{5}{|c|}{$\Delta$-carene + O } \\
\hline Mass & Formula & $\begin{array}{l}\text { Relative Mass } \\
\text { Difference (MFG) }\end{array}$ & RT & Notes \\
\hline 154.098 & C9 H14 O2 & 8.63 & 6.676 & a \\
\hline 186.0886 & C9 H14 O4 & 3.12 & 7.494 & a, c \\
\hline 184.1086 & C10 H16 O3 & 7.32 & 7.706 & b \\
\hline 114.0675 & C6 H10 O2 & 5.22 & 7.73 & \\
\hline 184.1094 & C10 H16 O3 & 3.15 & 8.155 & c \\
\hline 222.1209 & C11 H20 O3 & 10.28 & 8.211 & \\
\hline 184.1086 & C10 H16 O3 & 7.33 & 8.28 & \\
\hline 138.1032 & C9 H14 O & 8.99 & 8.311 & \\
\hline 200 & C11 H20 O3 & 7.55 & 8.434 & \\
\hline 92.0631 & C7 H8 & -4.95 & 8.44 & \\
\hline 122.1089 & C9 H14 & 5.05 & 8.442 & \\
\hline 106.0777 & C8 H10 & 5.1 & 8.445 & \\
\hline 168.1137 & C10 H16 O2 & 7.62 & 8.45 & \\
\hline 201.1353 & C10 H16 O3 & 5.94 & 9.029 & \\
\hline 138.1032 & C9 H14 O & 9.16 & 9.049 & \\
\hline 168 & C10 H16 O2 & 9.3 & 9.263 & \\
\hline 168 & C10 H16 O2 & 7.51 & 9.418 & \\
\hline 168.1139 & C10 H16 O2 & 6.93 & 9.523 & \\
\hline 170 & C10 H18 O2 & 6.74 & 10.032 & \\
\hline 222.0882 & C12 H14 O4 & 4.33 & 11.021 & \\
\hline & & & & \\
\hline
\end{tabular}




\begin{tabular}{|l|l|l|l|l|}
\hline 243.1813 & C13 H25 N O3 & 8.63 & 11.482 & $\mathrm{~b}$ \\
\hline 294.1457 & C16 H22 O5 & 3.55 & 11.833 & a \\
\hline 287.2808 & C17 H37 N O2 & 5.53 & 12.356 & \\
\hline 287.2807 & C17 H37 N O2 & 6.09 & 12.609 & \\
\hline 220.1082 & C13 H16 O3 & 7.97 & 13.055 & \\
\hline 160.0875 & C9 H14 O & & 13.055 & \\
\hline 276.1708 & C17 H24 O3 & 6.4 & 13.056 & \\
\hline 148.0147 & C8 H4 O3 & 9.37 & 13.681 & d \\
\hline 278.1501 & C16 H22 O4 & 6.25 & 13.682 & d \\
\hline 222.0881 & C12 H12 O3 & & 13.683 & a, d \\
\hline 148.0141 & C8 H4 O3 & 12.97 & 13.856 & d \\
\hline 278.1504 & C16 H22 O4 & 5.1 & 13.865 & d \\
\hline
\end{tabular}
a) Peak only appears in $\mathrm{O}_{3}$ experiment.
b) Peak present in both positive and negative ion mode.
c) Peak present in negative ion mode only.
d) Known phthalate impurity.

\begin{tabular}{|l|l|l|l|l|}
\hline \multicolumn{5}{|c|}{$\Delta$-carene + NO 3 (excluding products listed in $\Delta$-carene $+\mathrm{O}_{3}$ ) } \\
\hline Mass & Formula & $\begin{array}{l}\text { Relative Mass } \\
\text { Difference } \\
\text { (MFG) }\end{array}$ & RT & Notes \\
\hline 186.0878 & C9 H14 O4 & 7.6 & 6.51 & c \\
\hline 172.1084 & C9 H16 O3 & 9.06 & 6.946 & \\
\hline 152.1186 & C10 H16 O & 9.66 & 7.13 & \\
\hline 199.1193 & C10 H17 N O3 & 7.64 & 7.33 & \\
\hline 110.0725 & C7 H10 O & 5.7 & 7.498 & \\
\hline 168.1137 & C10 H16 O2 & 8.21 & 7.499 & \\
\hline 140.0825 & C8 H12 O2 & 9.09 & 7.514 & \\
\hline 211.155 & C12 H21 N O2 & 10.39 & 7.541 & \\
\hline 70.0419 & C4 H6 O & -0.86 & 7.731 & \\
\hline 138.1034 & C9 H14 O & 7.44 & 7.731 & \\
\hline 211.1548 & C12 H21 N O2 & 11.61 & 8.475 & \\
\hline 227.0772 & C10 H13 N O5 & 9.7 & 8.873 & \\
\hline 108.0566 & C7 H8 O & 8.81 & 9.298 & \\
\hline 200 & C10 H16 O4 & 8.31 & 9.406 & \\
\hline 199 & C9 H13 N O4 & 9.7 & 10.178 & \\
\hline 380.1585 & C18 H24 N2 O7 & -0.52 & 10.626 & \\
\hline 229.1663 & C12 H23 N O3 & 6.37 & 10.737 & \\
\hline 168 & C10 H16 O2 & 11.79 & 10.886 & \\
\hline 168 & C10 H16 O2 & 11.36 & 11.097 & \\
\hline 358.176 & C21 H26 O5 & 4.25 & 11.797 & \\
\hline 215 & C10 H17 N O4 & 10.75 & 11.853 & \\
\hline 134.1072 & C10 H14 & 17.16 & 11.855 & \\
\hline 200 & C11 H20 O3 & 14.23 & 11.863 & \\
\hline & & & & \\
\hline
\end{tabular}




\begin{tabular}{|l|l|l|l|l|}
\hline 472.1599 & C21 H28 O12 & 3.94 & 11.874 & \\
\hline 215 & C10 H17 N O4 & 9.89 & 11.966 & \\
\hline 168.1134 & C10 H16 O2 & 9.98 & 12.058 & \\
\hline 152.1187 & C10 H16 O & 9.42 & 12.059 & \\
\hline 215 & C10 H17 N O4 & 9.99 & 12.061 & \\
\hline 182.1285 & C11 H20 O3 & 11.75 & 12.079 & \\
\hline 243 & C11 H17 N O5 & 11.82 & 12.363 & \\
\hline 400.187 & C23 H28 O6 & 3.9 & 12.48 & \\
\hline 564.1592 & C25 H28 N2 O13 & -0.17 & 12.722 & \\
\hline 190.0977 & C10 H16 O2 & & 12.8 & \\
\hline 340.1651 & C21 H24 O4 & 6.91 & 12.803 & \\
\hline 478.2132 & C20 H34 N2 O11 & 6.42 & 13.748 & \\
\hline 312.1332 & C19 H20 O4 & 9.43 & 13.791 & \\
\hline 418.2283 & C19 H34 N2 O8 & 7.68 & 13.837 & \\
\hline 204.0769 & C12 H12 O3 & 8.34 & 13.893 & d \\
\hline 476 & C20 H32 N2 O11 & 4.91 & 14.72 & \\
\hline 413 & C20 H31 N O8 & 5.94 & 14.772 & \\
\hline 413 & C20 H31 N O8 & 5.48 & 14.932 & \\
\hline 476 & C20 H32 N2 O11 & 4.11 & 15.309 & \\
\hline 476 & C20 H32 N2 O11 & 4.2 & 15.501 & \\
\hline
\end{tabular}
a) Peak only appears in $\mathrm{O}_{3}$ experiment.
b) Peak present in both positive and negative ion mode.
c) Peak present in negative ion mode only.
d) Known phthalate impurity.

\begin{tabular}{|l|l|l|l|l|}
\hline \multicolumn{5}{|c|}{ limonene + O } \\
\hline Mass & Formula & $\begin{array}{l}\text { Relative Mass } \\
\text { Difference (MFG) }\end{array}$ & RT & Notes \\
\hline 154.0972 & C9 H14 O2 & 14.38 & 5.616 & \\
\hline 186.0868 & C9 H14 O4 & 13.14 & 7.438 & \\
\hline 80.0619 & C6 H8 & 8.6 & 7.438 & \\
\hline 126.0669 & C7 H10 O2 & 9.43 & 7.441 & \\
\hline 186.0871 & C9 H14 O4 & 11.07 & 7.701 & b \\
\hline 184.1072 & C10 H16 O3 & 14.71 & 7.754 & \\
\hline 184.1075 & C10 H16 O3 & 13.27 & 8.373 & b \\
\hline 200 & C11 H20 O3 & 12.66 & 8.667 & \\
\hline 92.0625 & C7 H8 & 1.56 & 8.674 & \\
\hline 132.0921 & C10 H12 & 13.52 & 8.682 & \\
\hline 122.1083 & C9 H14 & 10.11 & 8.684 & \\
\hline 168.1129 & C10 H16 O2 & 12.91 & 8.685 & \\
\hline 106.077 & C8 H10 & 11.72 & 8.685 & \\
\hline 188 & C9 H16 O4 & 12.51 & 9.177 & \\
\hline 222.0864 & C12 H14 O4 & 12.68 & 11.064 & \\
\hline 157.1446 & C9 H19 N O & 13.25 & 11.205 & \\
\hline
\end{tabular}




\begin{tabular}{|l|l|l|l|l|}
\hline 243.1803 & C13 H25 N O3 & 12.85 & 11.518 & $\mathrm{~b}$ \\
\hline 287.2792 & C17 H37 N O2 & 11.17 & 12.392 & \\
\hline 128.1183 & C8 H16 O & 14.21 & 12.399 & \\
\hline 216 & C12 H24 O3 & 11.07 & 12.406 & \\
\hline 287.2789 & C17 H37 N O2 & 12.16 & 12.649 & \\
\hline 314 & C18 H34 O4 & 14.78 & 13.084 & \\
\hline 276.1702 & C17 H24 O3 & 8.54 & 13.091 & \\
\hline 220.1072 & C13 H16 O3 & 12.36 & 13.099 & \\
\hline 330.1774 & C18 H28 O4 & 9.89 & 13.105 & \\
\hline 300.1657 & C14 H24 N2 O5 & 9.51 & 13.226 & \\
\hline 358 & C20 H38 O5 & 11.94 & 13.312 & \\
\hline 278.1487 & C16 H22 O4 & 11.26 & 13.732 & d \\
\hline 148.0138 & C8 H4 O3 & 15.22 & 13.732 & d \\
\hline 222.087 & C12 H14 O4 & 9.87 & 13.732 & a \\
\hline 312.1314 & C19 H20 O4 & 15.22 & 13.819 & \\
\hline 278.1491 & C16 H22 O4 & 9.8 & 13.918 & d \\
\hline 286.2102 & C16 H30 O4 & 14.65 & 14.828 & \\
\hline 402.2203 & C20 H34 O8 & 12.51 & 15.376 & \\
\hline
\end{tabular}
a) Peak only appears in $\mathrm{O}_{3}$ experiment.
b) Peak present in both positive and negative ion mode.
c) Peak present in negative ion mode only.
d) Known phthalate impurity.

\begin{tabular}{|l|l|l|l|l|}
\hline \multicolumn{5}{|c|}{ limonene + NO (excluding products listed in limonene $\left.+\mathrm{O}_{3}\right)$} \\
\hline Mass & Formula & $\begin{array}{l}\text { Relative Mass } \\
\text { Difference } \\
\text { (MFG) }\end{array}$ & RT & Notes \\
\hline 245.0868 & C10 H15 N O6 & 12.7 & 5.916 & \\
\hline 154.097 & C9 H14 O2 & 15.36 & 6.171 & \\
\hline 217.092 & C9 H15 N O5 & 13.76 & 6.584 & b \\
\hline 279 & C10 H17 N O8 & 13.3 & 6.658 & b \\
\hline 215 & C9 H13 N O5 & 13.8 & 7.522 & \\
\hline 217.0921 & C9 H15 N O5 & 12.87 & 8.491 & \\
\hline 227.076 & C10 H13 N O5 & 15.01 & 8.892 & \\
\hline 168.1124 & C10 H16 O2 & 15.8 & 9.381 & \\
\hline 245 & C10 H15 N1 O6 & 12.95 & 9.934 & \\
\hline 278.0727 & C9 H14 N2 O8 & 8.17 & 10.094 & c \\
\hline 294.1041 & C10 H18 N2 O8 & 7.42 & 10.148 & c \\
\hline 310.0985 & C10 H18 N2 O9 & 8.93 & 10.292 & c \\
\hline 338.0937 & C11 H18 N2 O10 & 7.19 & 10.331 & c \\
\hline 524.182 & C20 H32 N2 O14 & 6.4 & 10.568 & c \\
\hline 380.1558 & C18 H24 N2 O7 & 6.74 & 10.664 & \\
\hline 176.045 & C10 H8 O3 & 13.57 & 11.066 & \\
\hline 292.1277 & C16 H20 O5 & 11.45 & 11.694 & \\
\hline & & & & \\
\hline
\end{tabular}




\begin{tabular}{|l|l|l|l|l|}
\hline 358.1737 & C21 H26 O5 & 11.98 & 11.834 & \\
\hline 472.1564 & C27 H24 N2 O6 & 14.98 & 11.913 & \\
\hline 280.0698 & C17 H12 O4 & 13.32 & 12.035 & \\
\hline 492 & C20 H32 N2 O12 & 8.62 & 12.127 & \\
\hline 555 & C20 H33 N3 O15 & 10.67 & 12.187 & b \\
\hline 432 & C18 H28 N2 O10 & 8.23 & 12.245 & \\
\hline 290.1823 & C16 H28 O3 & 12.04 & 12.387 & \\
\hline 236.1743 & C15 H24 O2 & 14.2 & 12.389 & \\
\hline 492 & C20 H32 N2 O12 & 8.22 & 12.428 & \\
\hline 432 & C18 H28 N2 O10 & 9.88 & 12.495 & \\
\hline 492.1912 & C20 H32 N2 O12 & 8.77 & 12.528 & \\
\hline 218.1639 & C15 H24 O2 & 14.48 & 12.536 & \\
\hline 190.0965 & C12 H14 O2 & 15.27 & 12.839 & \\
\hline 432 & C18 H28 N2 O10 & 9.19 & 12.84 & \\
\hline 340.1631 & C21 H24 O4 & 13.12 & 12.84 & \\
\hline 446 & C19 H30 N2 O10 & 9.82 & 12.917 & \\
\hline 432 & C18 H28 N2 O10 & 10.16 & 13.009 & \\
\hline 509 & C19 H31 N3 O13 & 7.32 & 13.131 & \\
\hline 446 & C19 H30 N2 O10 & 9.82 & 13.192 & \\
\hline 509 & C19 H31 N3 O13 & 7.66 & 13.34 & \\
\hline 446 & C19 H30 N2 O10 & 9.84 & 13.342 & \\
\hline 523 & C20 H33 N3 O13 & 9.27 & 13.366 & \\
\hline 258.1795 & C14 H26 O4 & 13.94 & 13.515 & \\
\hline 476 & C20 H32 N2 O11 & 8.29 & 13.518 & \\
\hline 523 & C20 H33 N3 O13 & 8.02 & 13.564 & \\
\hline 482.1834 & C20 H32 N2 O10 & 8.71 & 13.712 & \\
\hline 446 & C19 H30 N2 O10 & 8.84 & 13.788 & \\
\hline 446 & C19 H30 N2 O10 & 9.18 & 13.915 & \\
\hline 204.076 & C12 H12 O3 & 12.92 & 13.927 & d \\
\hline 523 & C20 H33 N3 O13 & 8.38 & 14.278 & \\
\hline 460 & C20 H32 N2 O10 & 9.33 & 14.304 & \\
\hline 523 & C20 H33 N3 O13 & 8.98 & 14.834 & \\
\hline 358.2446 & C18 H34 N2 O5 & 5.98 & & \\
\hline 304.2374 & C20 H32 O2 & & \\
\hline
\end{tabular}

a) Peak only appears in $\mathrm{O}_{3}$ experiment.

b) Peak present in both positive and negative ion mode.

c) Peak present in negative ion mode only.

d) Known phthalate impurity. 
Table S.3. Masses and elemental composition for (a) all peaks with intensity greater than 10\% of the strongest peak observed in any of the ESI-MS spectra for each BVOC, (b) additional molecular formulae that have been identified by other studies, and (c) selected high-mass peaks. Possible molecular structures, which may be isomers of the true structure, are listed for most molecular formulae. As in Table S.2, masses and formulae refer to the precursor (non-adduct) compound, which is reported as the nominal mass for any adducts misassigned by the software.

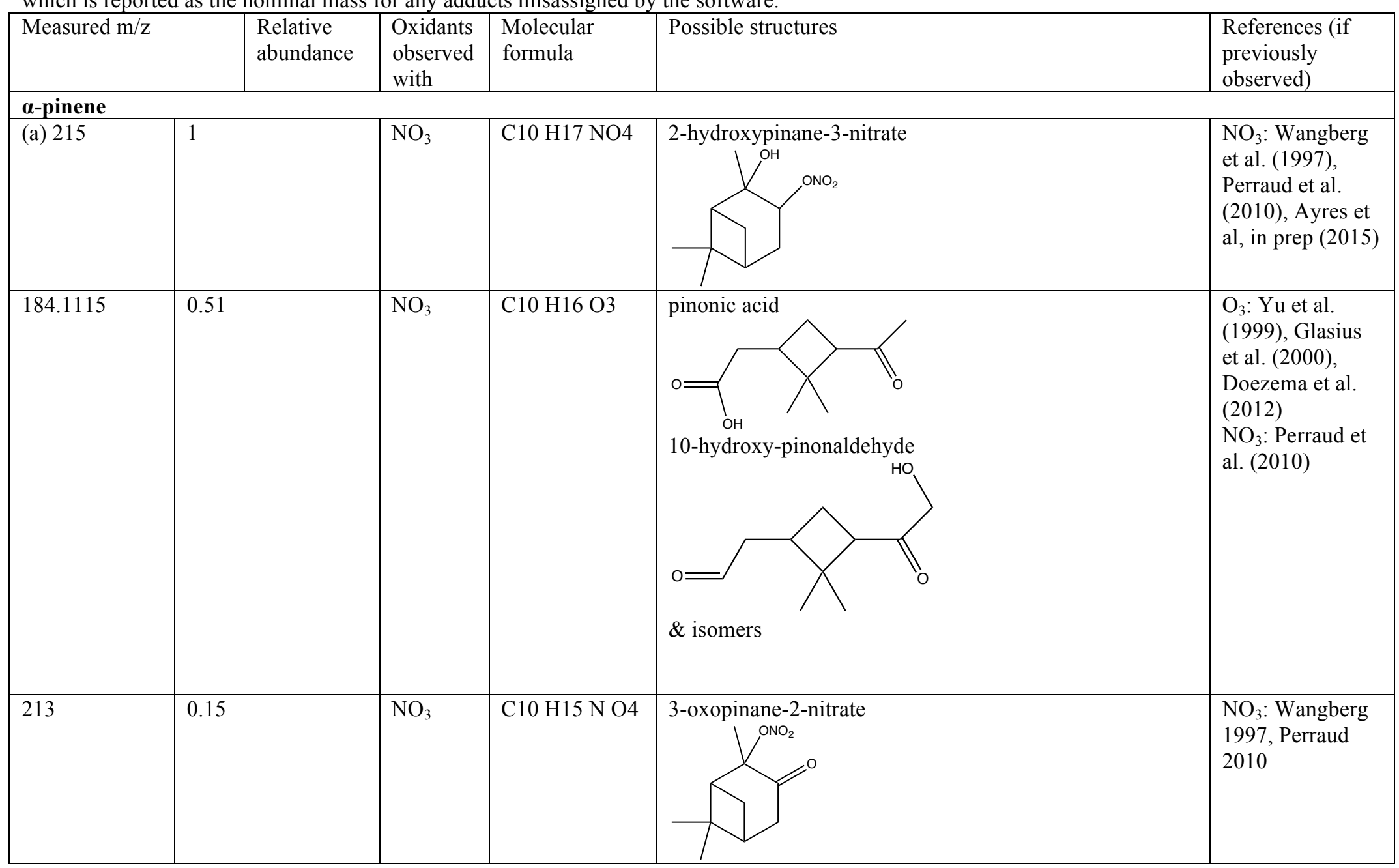




\begin{tabular}{|c|c|c|c|c|c|}
\hline 260 & 0.15 & $\mathrm{NO}_{3}$ & C10 H16 N2 O6 & 2,3-dinitrato-pinane & \\
\hline (b) 168.1166 & $0.08,0.04$ & $\mathrm{NO}_{3}, \mathrm{O}_{3}$ & $\mathrm{C} 10 \mathrm{H} 16 \mathrm{O} 2$ & pinonaldehyde & $\begin{array}{l}\mathrm{O}_{3} \text { : Glasius } \\
2000, \mathrm{Yu} \\
1999, \\
\text { Doezema et } \\
\text { al. (2012) } \\
\mathrm{NO}_{3} \text { : } \\
\text { Wangberg } \\
\text { et al. } \\
\text { (1997), } \\
\text { Hallquist et } \\
\text { al. (1999), } \\
\text { Perraud et } \\
\text { al. (2010) }\end{array}$ \\
\hline 231 & 0.07 & $\mathrm{NO}_{3}$ & C10 H17 N O5 & 2-hydroperoxypinane-3-nitrate & $\begin{array}{l}\mathrm{NO}_{3} \text { : Ayres } \\
\text { et al, in } \\
\text { prep (2015) }\end{array}$ \\
\hline 152.1214 & $0.05,0.02$ & $\mathrm{NO}_{3}, \mathrm{O}_{3}$ & C10 H16 O & pinane epoxide & $\begin{array}{l}\mathrm{NO}_{3} \text { : } \\
\text { Wangberg } \\
\text { et al. } \\
(1997)\end{array}$ \\
\hline (c) 383.1987 & 0.08 & $\mathrm{NO}_{3}$ & C19 H29 N O7 & & $\begin{array}{l}\text { speculative, } \\
\text { loosely } \\
\text { following } \\
\text { Heaton et } \\
\text { al. (2007) }\end{array}$ \\
\hline
\end{tabular}




\begin{tabular}{|c|c|c|c|c|c|}
\hline 366 & 0.05 & $\mathrm{NO}_{3}$ & $\mathrm{C} 20 \mathrm{H} 30 \mathrm{O} 6$ & 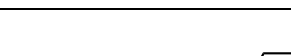 & speculative \\
\hline \multicolumn{6}{|l|}{$\beta$-pinene } \\
\hline (a) 138.1048 & $0.47,0.49$ & $\mathrm{NO}_{3}, \mathrm{O}_{3}$ & C9 H14 O & $\begin{array}{r}\text { nopinone } \\
\text { o }\end{array}$ & $\begin{array}{l}\mathrm{O}_{3} \text { : Glasius } \\
\text { et al. } \\
(2000) \text {, Yu } \\
\text { et al. } \\
(1999) \\
\mathrm{NO}_{3} \text { : } \\
\text { Hallquist et } \\
\text { al. (1999) }\end{array}$ \\
\hline 215 & 0.43 & $\mathrm{NO}_{3}$ & C10 H17 N O4 & hydroxynitrate & $\begin{array}{l}\mathrm{NO}_{3}: \text { Fry et } \\
\text { al. (2009), } \\
\text { Ayres in } \\
\text { prep (2015) }\end{array}$ \\
\hline 154.0999 & 0.29 .0 .30 & $\mathrm{NO}_{3}, \mathrm{O}_{3}$ & $\mathrm{C} 9 \mathrm{H} 14 \mathrm{O} 2$ & hydroxypinaketone & $\begin{array}{l}\mathrm{O}_{3} \text { : Glasius } \\
\text { et al. } \\
(2000), \mathrm{Yu} \\
\text { et al. } \\
(1999)\end{array}$ \\
\hline 429 & 0.28 & $\mathrm{NO}_{3}$ & C21 H35 N O8 & & \\
\hline 231 & 0.27 & $\mathrm{NO}_{3}$ & C10 H17 N O5 & dihydroxynitrate & $\begin{array}{l}\mathrm{NO}_{3}: \text { Fry et } \\
\text { al. (2009), } \\
\text { Ayres in } \\
\text { prep (2015) }\end{array}$ \\
\hline
\end{tabular}




\begin{tabular}{|c|c|c|c|c|c|}
\hline 227.0803 & 0.23 & $\mathrm{NO}_{3}$ & C10 H13 N O5 & $\mathrm{O}=\mathrm{ONO}_{2}$ & speculative \\
\hline 152.0842 & 0.18 & $\mathrm{NO}_{3}$ & C9 H12 O2 & 3-oxo-pinaketone & $\begin{array}{l}\mathrm{O}_{3}: \mathrm{Yu} \text { et } \\
\text { al. }(1999)\end{array}$ \\
\hline 230.1276 & 0.14 & $\mathrm{NO}_{3}$ & $\mathrm{C} 10 \mathrm{H} 18 \mathrm{~N} 2 \mathrm{O} 4$ & & \\
\hline 260 & 0.13 & $\mathrm{NO}_{3}$ & C10 H16 N2 O6 & $\mathrm{O}_{2} \mathrm{NO}$ & \\
\hline 385 & 0.13 & $\mathrm{NO}_{3}$ & C19 H31 N O7 & & $\begin{array}{l}\text { speculative, } \\
\text { loosely } \\
\text { following } \\
\text { Heaton et } \\
\text { al. (2007) }\end{array}$ \\
\hline 429 & 0.11 & $\mathrm{NO}_{3}$ & C21 H35 N O8 & & \\
\hline 184.1102 & 0.11 .0 .03 & $\mathrm{NO}_{3}, \mathrm{O}_{3}$ & C10 H16 O3 & pinonic acid & $\begin{array}{l}\mathrm{O}_{3} \text { : Glasius } \\
\text { et al. } \\
(2000)\end{array}$ \\
\hline
\end{tabular}




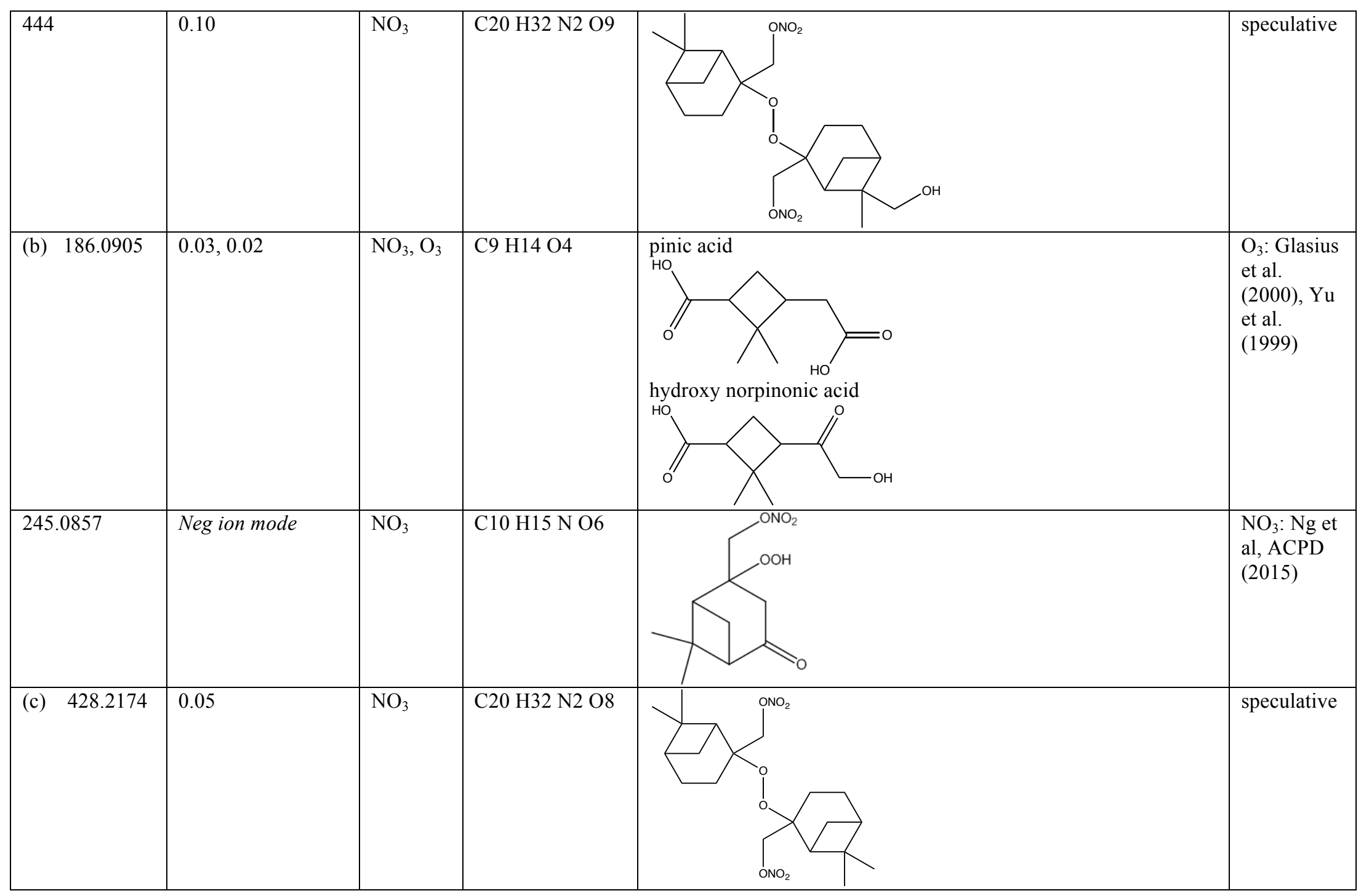




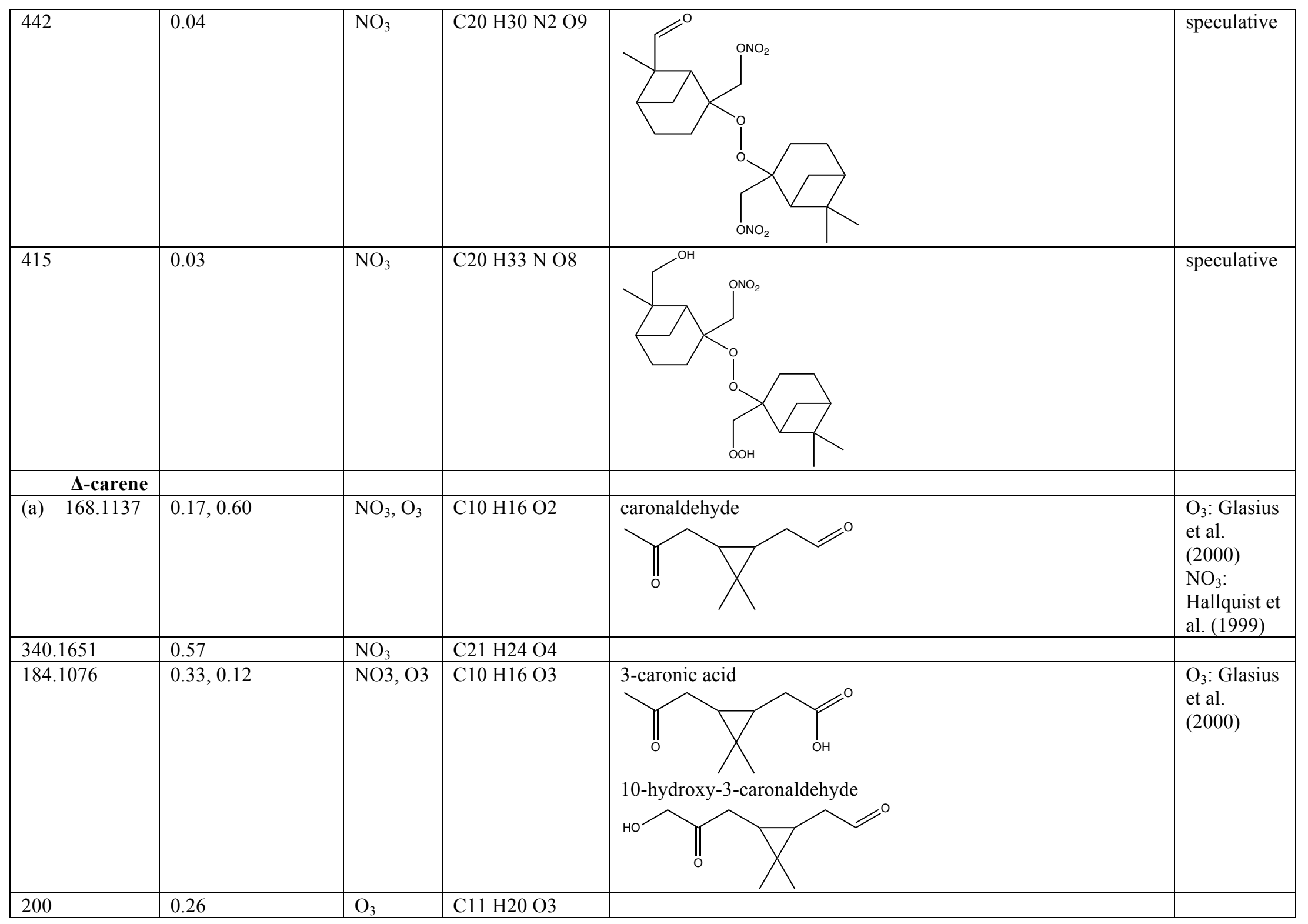




\begin{tabular}{|c|c|c|c|c|c|}
\hline 215 & 0.25 & $\mathrm{NO}_{3}$ & $\mathrm{C} 10 \mathrm{H} 17 \mathrm{~N} \mathrm{O} 4$ & hydroxynitrate & $\begin{array}{l}\mathrm{NO}_{3} \text { : } \\
\text { Colville } \\
\text { and Griffin } \\
(2004), \\
\text { Ayres in } \\
\text { prep (2015) }\end{array}$ \\
\hline 227.0772 & 0.13 & $\mathrm{NO}_{3}$ & C10 H13 N O5 & & $\begin{array}{l}\text { very } \\
\text { speculative } \\
!\end{array}$ \\
\hline 276.1708 & 0.12 & $\mathrm{NO}_{3}$ & $\mathrm{C} 17 \mathrm{H} 24 \mathrm{O} 3$ & & \\
\hline 243.1813 & 0.11 & $\mathrm{NO}_{3}$ & $\mathrm{C} 13 \mathrm{H} 25 \mathrm{~N} \mathrm{O} 3$ & & \\
\hline 186.0886 & $\begin{array}{l}\text { Neg ion } \\
\text { mode }\end{array}$ & & C9 H14 O4 & 3-caric acid & $\begin{array}{l}\mathrm{O}_{3}: \text { Glasius } \\
\text { et al. } \\
(2000), \mathrm{Yu} \\
\text { et al. } \\
(1999)\end{array}$ \\
\hline (c) 476 & 0.05 & $\mathrm{NO}_{3}$ & C20 H32 N2 O11 & & speculative \\
\hline 380.1585 & 0.04 & $\mathrm{NO}_{3}$ & $\mathrm{C} 18 \mathrm{H} 24 \mathrm{~N} 2 \mathrm{O} 7$ & & $\begin{array}{l}\text { Very } \\
\text { speculative! }\end{array}$ \\
\hline 413 & 0.04 & $\mathrm{NO}_{3}$ & $\mathrm{C} 20 \mathrm{H} 31 \mathrm{~N} \mathrm{O} 8$ & & \\
\hline
\end{tabular}




\begin{tabular}{|c|c|c|c|c|c|}
\hline 478.2132 & 0.03 & $\mathrm{NO}_{3}$ & C20 H34 N2 O11 & $r_{0}$ & $\begin{array}{l}\text { speculative } \\
- \text { this } \\
\text { formula is } \\
\text { consistent } \\
\text { with some } \\
\text { ring- } \\
\text { opening in } \\
\text { the dimer }\end{array}$ \\
\hline 418.2283 & 0.03 & $\mathrm{NO}_{3}$ & C19 H34 N2 O8 & \rangle & $\begin{array}{l}\text { speculative } \\
\text { - also } \\
\text { consistent } \\
\text { with ring- } \\
\text { opened } \\
\text { products }\end{array}$ \\
\hline \multicolumn{6}{|c|}{ limonene } \\
\hline (a) 340.1631 & 0.37 & $\mathrm{NO}_{3}$ & $\mathrm{C} 21 \mathrm{H} 24 \mathrm{O} 4$ & Extremely low $\mathrm{H}: \mathrm{C}$ ratio, has to be very conjugated & \\
\hline 168.1125 & $0.30,0.27$ & $\mathrm{NO}_{3}, \mathrm{O}_{3}$ & $\mathrm{C} 10 \mathrm{H} 16 \mathrm{O} 2$ & limonaldehyde/endolim & $\begin{array}{l}\mathrm{O}_{3} \text { : Glasius } \\
\text { et al. } \\
(2000) \text {, } \\
\text { Walser et } \\
\text { al. (2008) } \\
\mathrm{NO}_{3} \text { : } \\
\text { Spittler et } \\
\text { al. (2006), } \\
\text { Hallquist et } \\
\text { al. (1999), } \\
\text { Fry et al. } \\
\text { (2011) }\end{array}$ \\
\hline
\end{tabular}




\begin{tabular}{|c|c|c|c|c|c|}
\hline 186.0868 & $0.12,0.28$ & $\mathrm{NO}_{3}, \mathrm{O}_{3}$ & C9 H14 O4 & limonic acid: & $\begin{array}{l}\mathrm{O}_{3} \text { : Glasius } \\
\text { et al. } \\
\text { (2000), } \\
\text { Walser et } \\
\text { al. }(2008)\end{array}$ \\
\hline 182.128 & $0.15,0.14$ & $\mathrm{NO}_{3}, \mathrm{O}_{3}$ & $\mathrm{C} 11 \mathrm{H} 18 \mathrm{O} 2$ & & \\
\hline 268 & 0.12 & $\mathrm{NO}_{3}$ & $\mathrm{C} 16 \mathrm{H} 28 \mathrm{O} 3$ & & \\
\hline
\end{tabular}




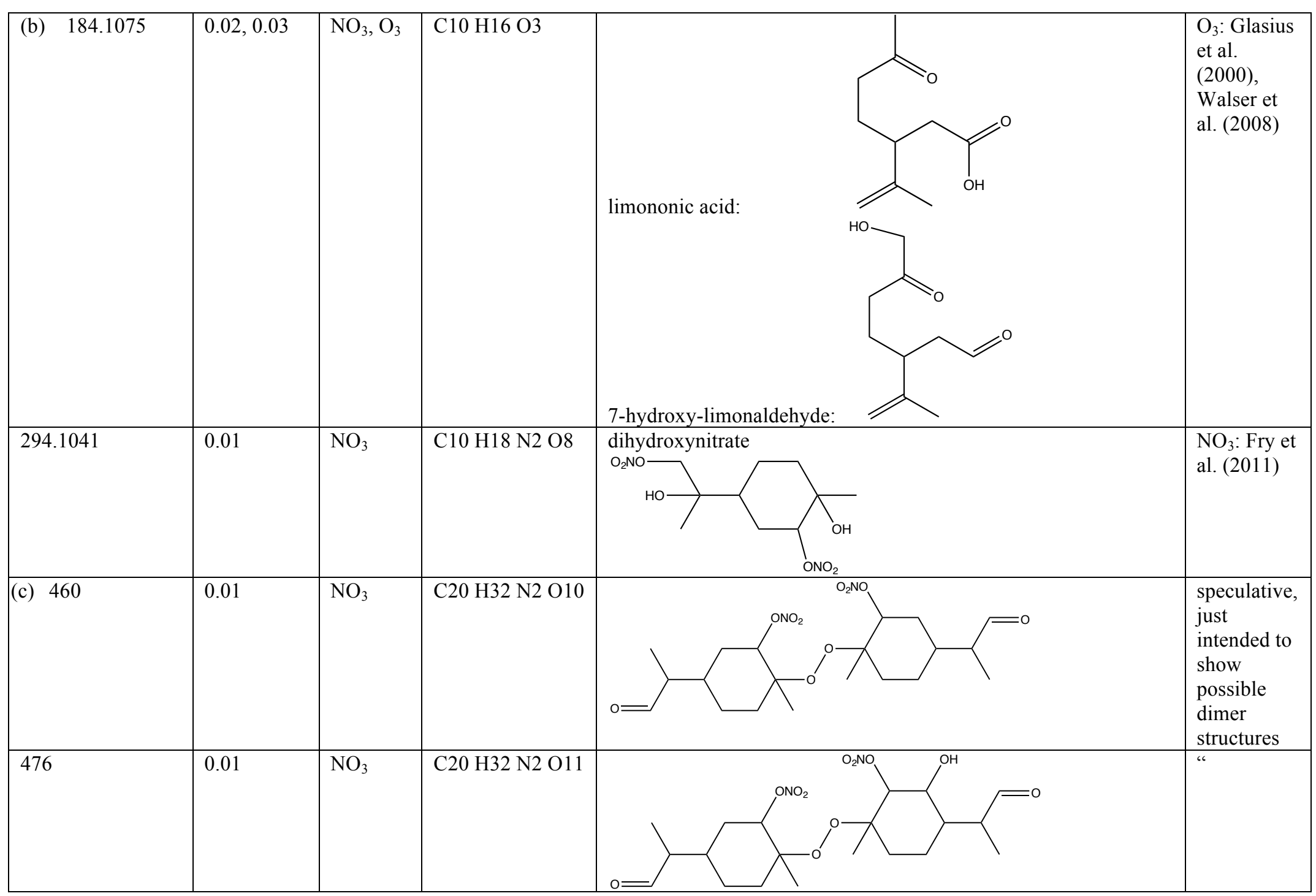




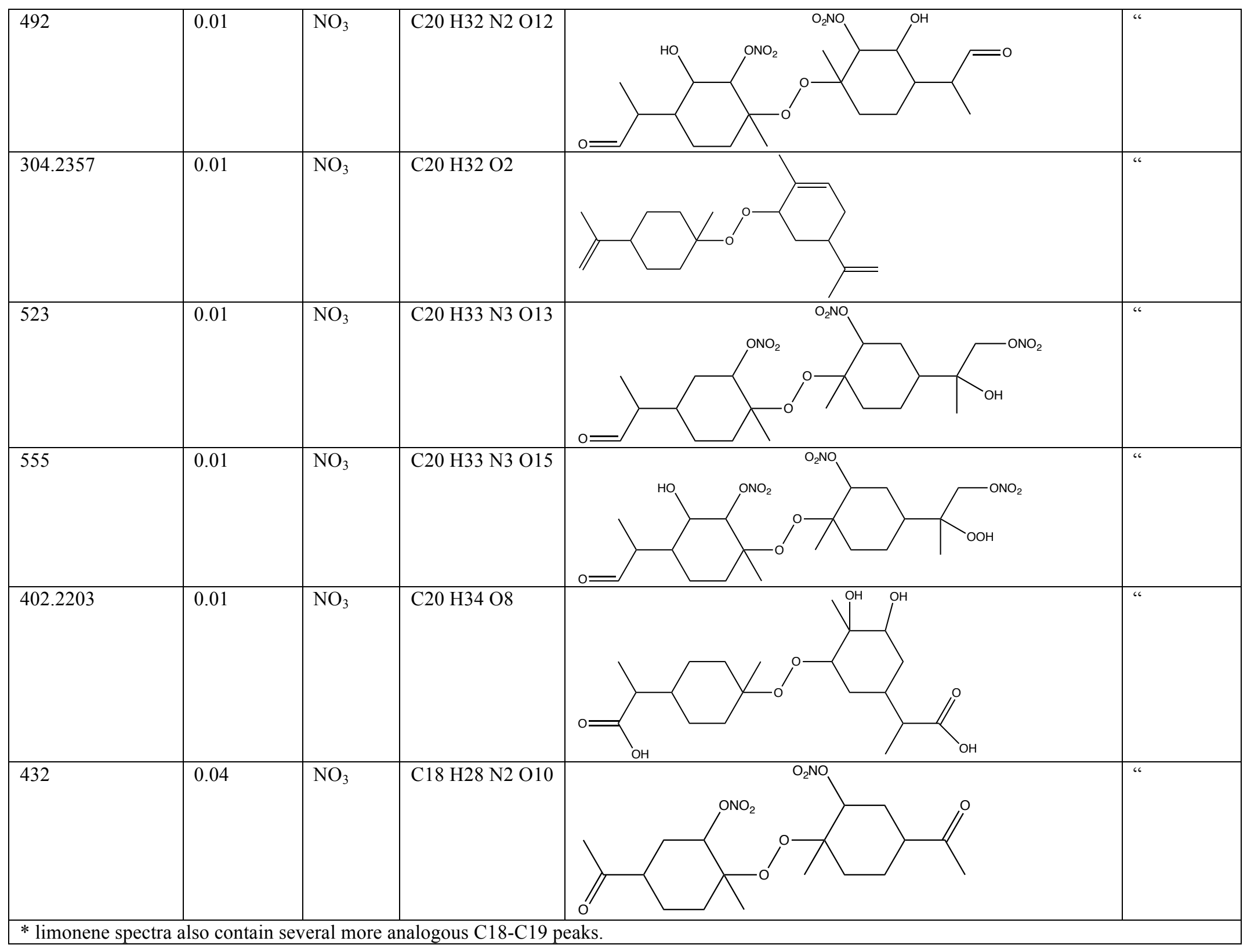




\section{References}

Andres-Hernandez, M. D., Kartal, D., Crowley, J. N., Sinha, V., Regelin, E., Martinez Harder, M., Nenakhov, V., Williams, J., Harder, H., Bozem, H., Song, W., Thieser, J., Tang, M. J., Hosaynali Beigi, Z., Burrows, J. P.: Diel peroxy radicals in a semi-industrial coastal area: nighttime formation of free radicals, Atmospheric Chemistry and Physics, 13, 5731-5749, doi:10.5194/acp-13-5731-2013, 2013.

Atkinson, R.: Atmospheric Reactions of Alkoxy and $\beta$-Hydroxyalkoxy Radicals, International Journal of Chemical Kinetics, 29, 99-111, doi: 10.1002/(SICI)10974601(1997)29:2<99::AIDKIN3>3.0.CO;2-F, 1997.

Atkinson, R. and Arey, J.: Atmospheric Degradation of Volatile Organic Compounds, Chemical Reviews, 103, 4605-4638, doi:10.1021/cr0206420, http://pubs.acs.org/doi/abs/10.1021/cr0206420, 2003.

Atkinson, R., Aschmann, S. M., Arey, J., and Shorees, B.: Formation of OH radicals in the gas phase reactions of $\mathrm{O} 3$ with a series of terpenes, Journal of Geophysical Research: Atmospheres, 97, 6065-6073, doi:10.1029/92JD00062, http://dx.doi.org/10.1029/92JD00062, 1992.

Atkinson, R.,: Gas-Phase Tropospheric Chemistry of Volatile Organic Compounds: 1. Alkanes and Alkenes, Journal of Physical and Chemical Reference Data, 26, 215-290, doi:http://dx.doi.org/10.1063/1.556012, 1997.

Atkinson, R., Baulch, D. L., Cox, R. A., Crowley, J. N., Hampson, R. F., Hynes, R. G., Jenkin, M. E., Rossi, M. J., and Troe, J.: Evaluated kinetic and photochemical data for atmospheric chemistry: Volume I - gas phase reactions of $\mathrm{O}_{\mathrm{x}}, \mathrm{HO}_{\mathrm{x}}, \mathrm{NO}_{\mathrm{x}}$ and $\mathrm{SO}_{\mathrm{x}}$ species, Atmos. Chem. Phys., 4, 1461-1738, doi:10.5194/acp-4-1461-2004, 2004.

Boyd, C. M., Sanchez, J., Xu, L., Eugene, A. J., Nah, T., Tuet, W. Y., Guzman, M. I., and $\mathrm{Ng}$, N. L.: Secondary Organic Aerosol (SOA) formation from the $\beta$-pinene $+\mathrm{NO}_{3}$ system: effect of humidity and peroxy radical fate, Atmospheric Chemistry and Physics Discussion, 15, 26792744, doi:10.5194/acpd-15-2679-2015, 2015.

Colville, C. J. and Griffin, R. J.:The roles of individual oxidants in secondary organic aerosol formation from $\Delta^{3}$-carene: 1. gas-phase chemical mechanism, Atmospheric Environment, 38, 4001-4012, 2004.

DeMore, W. G., Sander, S. P., Golden, D. M., Hampson, R. F., Kurylo, M. J., Howard, C.J., Ravishankara, A. R., Kolb, C. E., and Molina, M. J.: Chemical Kinetics and Photochemical Data for Use in Stratospheric Modeling, Evaluation Number 11, JPL Publication, 94-26, 1994.

Doezema, L. A., Longin, T., Cody, W., Perraud, V., Dawson, M. L., Ezell, M. J., Greaves, J., Johnson, K. R., and Finlayson-Pitts, B. J.: Analysis of secondary organic aerosols in air using extractive electrospray ionization mass spectrometry (EESI-MS), RSC Adv., 2, 2930-2938, doi:10.1039/C2RA00961B, 2012. 
Ehn, M., Thornton, J. A., Kleist, E., Sipila, M., Junninen, H., Pullinen, I., Springer, M., Rubach, F., Tillmann, R., Lee, B., Lopez-Hilfiker, F., Andres, S., Acir, L-H., Rissanen, M., Jokinen, T., Schobesberger, S., Kangasluoma, J., Kontkanen, J., Nieminen, T., Kurten, T., Nielsen, L. B., Jorgensen, S., Kjaergaard, H. G., Canagaratna, M., Maso, M. D., Berndt, T., Petaja, T., Wahner, A., Kerminen, V. M., Kulmala, M., Worsnop, D. R., Wildt, J., and Mentel, T. F.: A large source of low-volatility secondary organic aerosol, Nature, 506, 476-479, doi:10.1038/nature13032, 2014.

Fry, J. L., Kiendler-Scharr, A., Rollins, A. W., Woodridge, P. J., Brown, S. S., Fuchs, H., Dube, W., Mensah, A., dal Maso, M., Tillmann, R., Dorn, H. P., Brauers, T., and Cohen, R. C.: Organic nitrate and secondary organic aerosol yield from NO3 oxidation of $\beta$-pinene evaluated usaing a gas-phase kinetics/aerosol partitioning model, Atmospheric Chemistry and Physics, 9, 14311449, doi:10.5194/acp-91431-2009, 2009.

Fry, J. L., Kiendler-Scharr, A., Rollins, A. W., Brauers, T., Brown, S. S., Dorn, H. P., Dube, W. P., Fuchs, H., Mensah, A., Rohrer, F., Tillmann, R., Wahner, A., Woodridge, P. J., and Cohen, R. C.: SOA from limonene: role of NO3 in its generation and degradation, Atmospheric Chemistry and Physics, 11, 3879-3894,doi:10 .5194/acp-11-3879-2011, 2011.

Fry, J. L., Draper, D. C., Barsanti, K. C., Smith, J. N., Ortega, J., Winkler, P. M., Lawler, M. J., Brown, S. S., Edwards, P. M., Cohen, R. C., and Lee, L.: Secondary Organic Aerosol Formation and Organic Nitrate Yield from NO3 Oxidation of Biogenic Hydrocarbons, Environmental Science \& Technology, 48, 11944-11953, doi:10.1021/es502204x, 2014.

Glasius, M., Lahaniati, M., Calogirou, A., Di Bella, D., Jensen, N. R., Hjorth, J., Kotzias, D., and Larsen, B. R.: Carboxylic Acids in Secondary Aerosols from Oxidation of Cyclic Monoterpenes by Ozone, Environmental Science \& Technology, 34, 1001 1010, doi:10.1021/es990445r, 2000.

Hallquist, M., Wangberg, I., Ljungstrom, E., Barnes, I., and Becker, K. H.: Aerosol and Product Yields from NO3 Radical-Initiated Oxidation of Selected Monoterpenes, Environmental Science \& Technology, 33, 553-559, doi:10.1021/es980292s, 1999.

Haynes, W., Bruno, T. J., and Lide, D. R., eds.: CRC Handbook of Chemistry and Physics, $93^{\text {rd }}$ Edition (Internet Version), CRC Press/Taylor and Francis, 2012.

Heaton, K. J., Dreyfus, M. A., Wang, S., and Johnston, M. V.: Oligomers in the Early Stage of Biogenic Secondary Organic Aerosol Formation and Growth, Environmental Science \& Technology, 41, 6129-6136, doi:10.1021/es070314n, 2007.

Lightfoot, P. D., Cox, R. A., Crowley, J. N., Destriau, M., Hayman, G. D., Jenkin, M. E., Moortgat, G. K., Zabel, F.: Organic peroxy radicals: Kinetics, spectroscopy and tropospheric chemistry, Atmospheric Enviroment Part A-General Topics, 26, 1805-1961, doi:10.1016/09601686(92)90423-I, 1992. 
McMurry, P. H. and Grosjean, D.: Gas and aerosol wall losses in Teflon film smog chambers, Environmental Science and Technology, 19, 1176-1182, doi:10.1021/es00142a006, 1985.

Orlando, J. J. and Tyndall, G. S.: Laboratory studies of organic peroxy radical chemistry: an overview with emphasis on recent issues of atmospheric significance, Chem. Soc. Rev., 41, 6294-6317, doi:10.1039/c2cs35166h, 2012.

Perraud, V., Bruns, E. A., Ezell, M. J., Johnson, S. N., Greaves, J., and Finlayson-Pitts, B. J.: Identification of Organic Nitrates in the NO3 Radical Initiated Oxidation of $\alpha$-Pinene by Atmospheric Pressure Chemical Ionization Mass Spectrometery, Environmental Science \& Technology, 44, 5887-5893, doi:10.1021/es1005658, 2010.

Sander, S., Abbatt, J., Barker, J. R., Burkholder, J. B., Friedl, R. R., Golden, D. M., Huie, R. E., Kolb, C. E., Kurylo, M. J., Moortgat, G. K., Orkin, V. L., and Wine, P. H.,: Chemical Kinetics and Photochemical Data for Use in Atmospheric Studies, Evaluation Number 17, JPL Publication, 10, 2011.

Spittler, M., Barnes, L., Bejan, I., Brockmann, K., Benter, T., and Wirtz, K.: Reactions of NO3 radicals with limonene and $\alpha$-pinene: Product and SOA formation, Atmospheric Environment, 40, Supplement 1, 116-127, doi:10.1016/j.atmosenv.2005.09.093, 2006.

Vaughan, S., Canosa-Mas, C. E., Pfrang, C., Shallcross, D. E., Watson, L., Wayne, R. P.: Kinetic studies of reactions of the nitrate radical (NO3) with peroxy radicals (RO2): an indirect source of $\mathrm{OH}$ at night?, Phys. Chem. Chem. Phys., 8, 3749-3760, doi:10.1039/b605569a, 2006.

Walser, M. L., Desyaterik, Y., Laskin, J., Laskin, A., and Nizkorodov, S. A.: Highresolution mass spectrometric analysis of secondary organic aerosol produced by ozonation of limonene, Phys. Chem. Chem. Phys, 10, 1009-1022, doi:10.1039/B712620D, 2008.

Wangberg, I., Barnes, I., and Becker, K. H.: Product and Mechanistic Study of the Reaction of NO3 Radicals with $\alpha$-pinene, Environmental Science \& Technology, 31, 2130-2135, doi:10.1021/es960958n, 1997.

Wolfe, G. M., Cantrell, C., Kim, S., Mauldin III, R. L., Karl, T., Harley, P., Turnipseed, A., Zheng, W., Flocke, F., Apel, E. C., Hornbrook, R. S., Hall, S. R., Ullmann, K., Henry, S. B., DiGangi, J. P., Boyle, E. S., Kaser, L., Schnitzhofer, R., Hansel, A., Graus, M., Nakashima, Y., Kajii, Y., Guenther, A., Keutsch, F. N.: Missing peroxy radical sources within a summertime ponderosa pine forest, Atmospheric Chemistry and Physics, 14, 4715-4732, doi:10.5194/acp-144715-2014, 2014.

Yu, J., Cocker, D., Griffin, R., Flagan, R., and Seinfeld, J.: Gas-phase ozone oxidation of monoterpenes: Gaseous and particulate products, Journal of Atmospheric Chemistry, 34, 207258, 1999.

Zhang, J., Huff Hartz, K. E., Pandis, S. N. and Donahue, N. M.: Secondary Organic Aerosol Formation from Limonene Ozonolysis: Homogeneous and Heterogeneous Influences as a 
Function of NOx, Journal of Physical Chemistry A, 110(38), 11053-11063, doi:10.1021/jp062836f, 2006.

Ziemann, P. J., and Atkinson, R.: Kinetics, products, and mechanisms of secondary organic aerosol formation, Chem. Soc. Rev., 41, 6582-6605, doi:10.1039/c2cs35122f, 2012. 